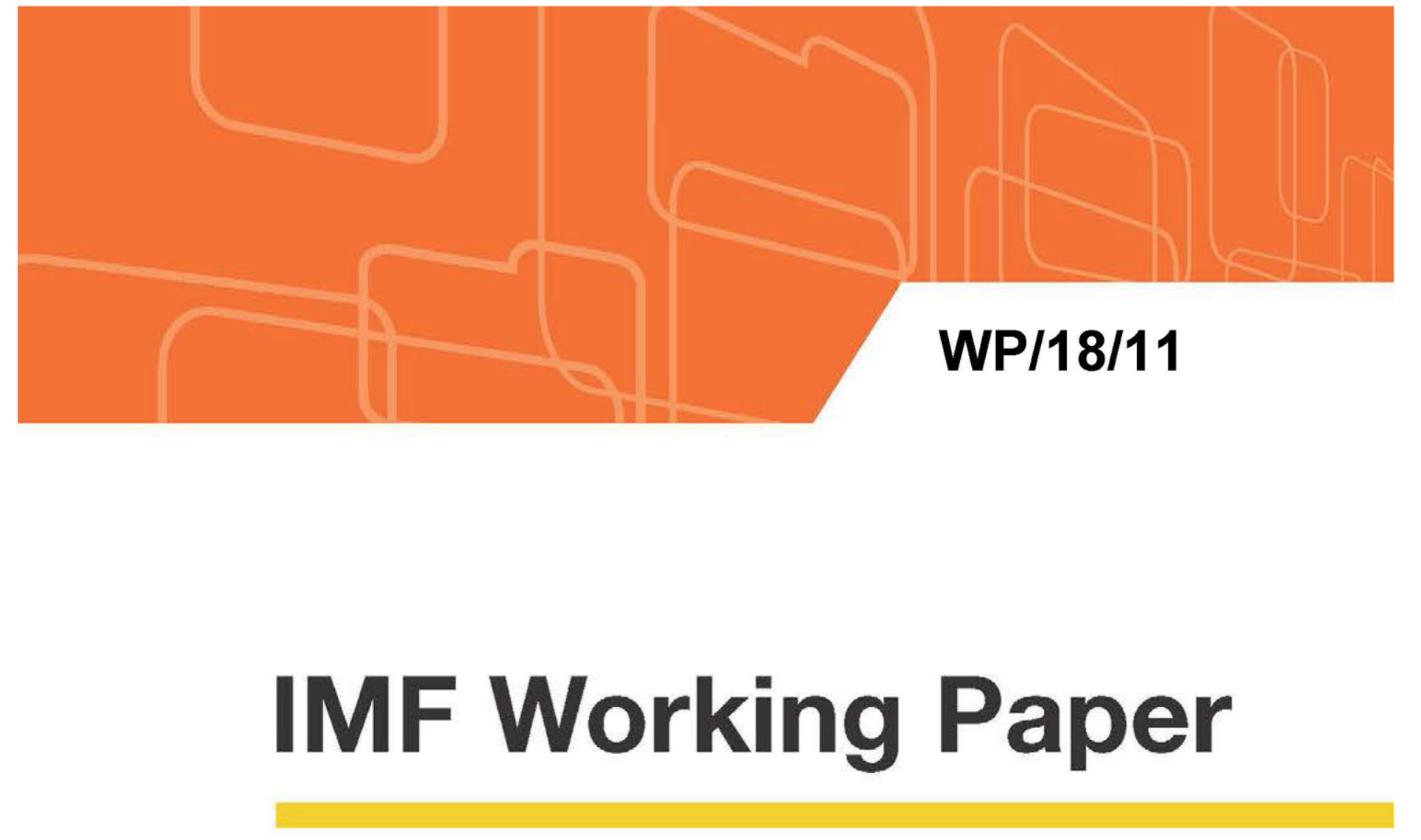

\title{
A New Wave of ECB's Unconventional Monetary Policies: Domestic Impact and Spillovers
}

Richard Varghese and Yuanyan Sophia Zhang

IMF Working Papers describe research in progress by the author(s) and are published to elicit comments and to encourage debate. The views expressed in IMF Working Papers are those of the author(s) and do not necessarily represent the views of the IMF, its Executive Board, or IMF management. 


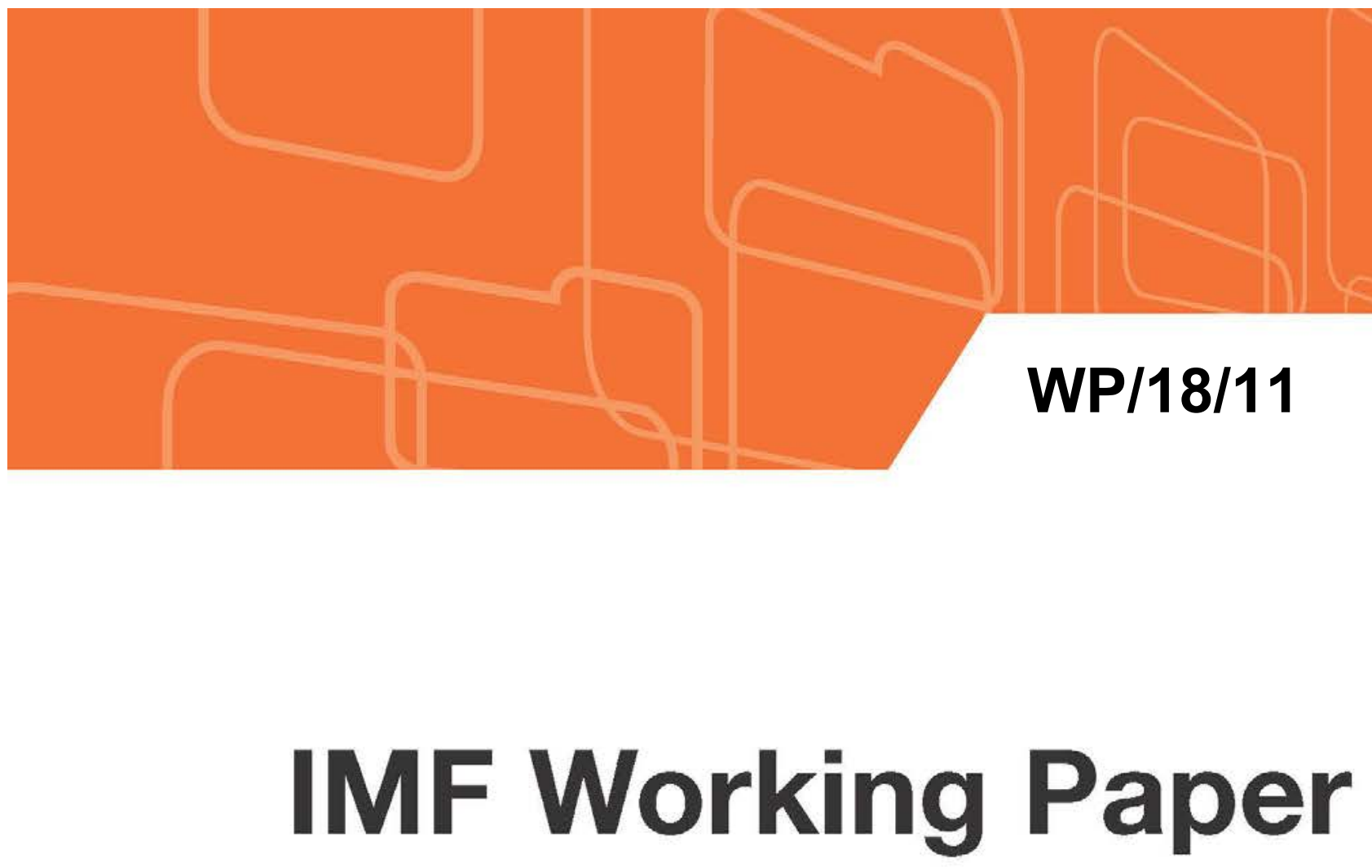

\section{A New Wave of ECB's Unconventional Monetary Policies: Domestic Impact and Spillovers}

Richard Varghese and Yuanyan Sophia Zhang

IMF Working Papers describe research in progress by the author(s) and are published to elicit comments and to encourage debate. The views expressed in IMF Working Papers are those of the author(s) and do not necessarily represent the views of the IMF, its Executive Board, or IMF management.

$$
\text { I N T ER N A T I O N A L M O N E T A R Y F U N D }
$$




\title{
IMF Working Paper
}

Strategy Policy and Review

\section{A New Wave of ECB's Unconventional Monetary Policies: Domestic Impact and Spillovers}

\section{Prepared by Richard Varghese and Yuanyan Sophia Zhang}

Authorized for distribution by Vikram Haksar

January 2018

\section{IMF Working Papers describe research in progress by the author(s) and are published to elicit comments and to encourage debate. The views expressed in IMF Working Papers are those of the author(s) and do not necessarily represent the views of the IMF, its Executive Board, or IMF management.}

\begin{abstract}
ECB President Draghi's Jackson Hole speech in August 2014 arguably marked a new phase of unconventional monetary policies (UMPs) in the euro area. This paper examines the market impact and tranmission channels of this new wave of UMPs using a modified event study framework. They are found to have a more prominent impact on inflation expectations and exchange rates compared to the earlier UMP announcements. The impact on bank equity, however, is less significant in part due to narrowing profit margin in a low interest rate environment; and the marginal effect on sovereign spread compression has diminished. By extracting components of monetary policy shocks from the yield curve, we find that the traditional signaling channel of the monetary policy transmission continued to play an important role, but the portfolio rebalancing channel became more important in the new phase. Spillovers to non-euro area EU countries (the Czech Republic, Denmark, Poland, and Sweden) are transmitted mainly through the portfolio rebalancing channel, largely affecting sovereign yields and exchange rates.
\end{abstract}

JEL Classification Numbers: E40, E50

Keywords: Yield Curve, Quantitative Easing, Event Study

Author's E-Mail Address: richard.varghese@graduateinstitute.ch; yzhang@imf.org 


\section{Contents}

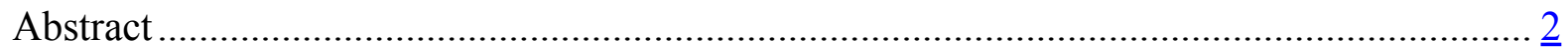

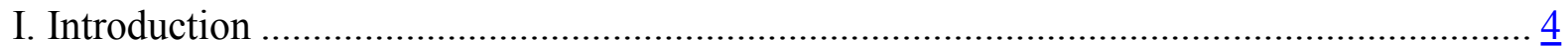

II. A Measure of Monetary Policy Surprise …………................................................... 7

III. Empriical Framework …………………………….......................................... 13

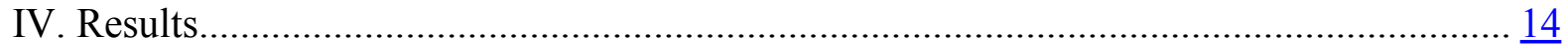

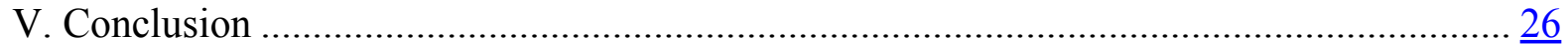

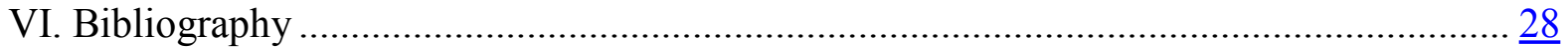




\section{INTRODUCTION}

ECB president Mario Draghi's Jackson Hole speech in August 2014 clearly marked a new phase of unconventional monetary policies (UMPs) in the euro area. Unlike the earlier phase that aimed to relieve financial and sovereign stress triggered by crises, ${ }^{1}$ the new phase was initiated to address persistently weak growth prospects and the risk of a prolonged period of low inflation. The new measures, including asset purchase programs, are expected to increase credit supply to the private sector, stimulate economic activity, and support inflation expectations through various (signaling, credit/bank lending, and portfolio rebalancing) transmission channels of the monetary policy. In this context, it is important to understand the macroeconomic and financial impact of this new wave of UMPs introduced by the ECB, their transmission channels, and their unintended consequences that may raise future financial stability concerns.

There is a rich strand of literature that has examined the impact of ECB's UMPs on domestic asset prices (Rogers et al., 2014; Fratzscher, et al., 2016; Altavilla, et al., 2015; Pereira, 2016), real economic variables (Altavilla, et al., 2014; Wieladek and Pascual, 2016) and spillovers to foreign (non-euro area European) markets (Fratzscher, et al., 2016; Falagiarda, et al., 2015; Georgiadis and Gräb, 2015; Ciarlone and Colabella, 2016; IMF, 2016). While most papers find that UMPs lower long term yields, mitigate market fragmentation in sovereign bond markets (e.g. Fratzscher, et al. 2016; Rogers et al., 2014; Inez, 2016), and raise equity returns (e.g. Fratzscher, et al. 2016); their views on exchange rates are rather divided. Rogers et al, (2014) finds that euro appreciates after the initial set of UMPs; ${ }^{2}$ while Georgiadis and Gräb (2015) claims the opposite for the Expanded Asset Purchase (EAP) Programme announced on 22 January 2015. International spillovers are found to be transmitted mainly through bond yields and exchange rates, and have become more prominent in the new phase, especially for countries with strong economic and financial ties with the euro area (IMF, 2016 and Falagiarda, et al., 2015. There is also some evidence of positive macroeconomic impact from the UMPs. Wieladek and Pascual (2016) estimate that in absence of the EAP, real GDP and core CPI would have been $1.3 \%$ and $0.9 \%$ lower, respectively, in a counterfactual scenario. Anecdotal and survey (ECB, 2016) evidence suggest some loosening of bank lending standards and improving credit demand. Altavilla, et al. (2014), using high-frequency data and scenario analysis, suggests that the reduction in bond yields following OMT announcements supports a significant increase in real activity, credit, and prices in periphery economies in the euro area, and a relatively muted impact on core euro area countries.

\footnotetext{
${ }^{1}$ The global financial crisis followed by the sovereign debt crisis in the euro area.

2 They consider LTRO-type and bond purchases announcements till June 2013.
} 
Despite the growing literature on ECB's UMPs, some key questions remain unaddressed. First, how do bank equity returns and inflation expectations react to UMP announcements? This is a particularly important question to ask in the current conjucture for two reasons. First, while the pre-QE UMPs were expected to raise bank equity returns and lower sovereign stress during the crisis, the $\mathrm{QE}$ announcements ${ }^{3}$ may have a mixed impact on bank equity returns given a prolonged period of low and increasingly negative interest rate environment. This could adversely affect banks' profit margin and undermine the bank lending channel. Second, it has become increasingly important for the central bank to anchor inflation expectations in a deflationary environment as failure to do so may influence policymakers credibility. Hence, it is crucial to understand the effectiveness of QEs in supporting inflation expectations and their implications on bank profitability and financial stability more broadly.

Second, what are the channels through which ECB's UMPs affect financial markets? There has been only very limited attempt in literature to quantitatively analyse the transmission channels through which ECB's QE affect financial markets. To fill this gap, we extract monetary policy shocks from yield curves and decompose them into factors that capture signaling and portfolio rebalancing channels. The signaling channel is expected to stimulate aggregate demand by "signaling" ECB's commitment to maintain an accommodative monetary policy stance over many years. ${ }^{4}$ Portfolio rebalancing channel works through market demand and supply of government securities; that is, through ECB's exchange of longer-term and relatively less liquid assets for very short-term and highly liquid central bank assets. This lowers long term government bond yields, raises riskier asset prices and pumps excess liquidity into the market. This in turn strengthens balance sheet conditions, relax borrowing constraints, and ease credit availability for firms and households, and thereby stimulate spending. We examine the relative importance of both channels.

Finally, is the new wave of QEs different from earlier UMPs? As discussed earlier in the ECB report to an array of unconventional policy measures before undertaking purchases of public (and corporate) sector securities, widely referred to as QE in the US and the UK context. While the initial set of UMPs from the ECB, which we label as pre-QE UMPs, were primarily aimed at providing liquidity to and preventing the meltdown of the European financial system, the recent $\mathrm{QE}$ announcements were intended to stimulate the economy and provide further

\footnotetext{
${ }^{3}$ By QE announcement we refer to ECB's asset purchase programs that were not sterilized nor linked to any conditionality. Specifically, it refers to the following events: ECB President Mario Draghils Jackson Hole speech on August 22, 2014 that signaled the likelihood of outright QE in the euro area as understood in the United States and the United Kingdom as well as asset purchase programmes announced on January 22, 2015 and March 10, 2016.

${ }^{4}$ For example, TLTROs (Targeted Long Term Refinancing Operations) indicate the likely path of future interest rates through their pre-specified interest rate and their maturity extending over many years and asset purchases indirectly through the expansion of the Eurosystem's balance sheet (Constâncio, 2015).
} 
accommodation at the zero lower bound after the central bank explicitly acknowledged deflationary pressures in the single currency union. Therefore, it is important to understand how QEs influence the market differently from the earlier UMPs in the euro area context.

To examine the three questions raised above, we modify the traditional event study approach. The traditional approach that identifies events using announcement dummies does not capture the size and sign of actual monetary policy shocks on the event dates and the market's anticipation prior to them. This is particularly true for the recent QE announcements, which were too eagerly anticipated and had significant anticipation effects. The announcement on March 2016, for example, was an easing announcement. However, it generated a tightening surprise as markets were anticipating a more accomodative announcement. To address this concern, following Chen, et al. (2014), we build a measure of surprise to capture the unexpected element of monetary policy announcements irrespective of policy instruments policy rate changes, asset purchases or forward guidance. ${ }^{5}$ Controlling for the unexpected component of monetary policy announcements is critical to accurately measure the market impact and spillovers of the UMP announcements. To the best of our knowledge, this is the first attempt to build such a monetary policy surprise index for ECB's policies. The surprise index provides us information about market's prior expectations going into a monetary policy announcement. We also analyse and document the patterns in these surprises during various phases of the ECB's monetary policy. The monetary policy surprises can be positive (tightening) or negative (loosening) on the event dates; and are decomposed into signalling and portfolio rebalancing factors.

Consistent with the existing research, UMP announcements in general are found to be associated with higher equity returns, lower sovereign yields and smaller sovereign spreads between core and non-core EAs; while the impact on exchange rates is muted. Encouragingly, they are also found to be supportive of higher inflation expectations (market-based measure) and bank equity returns (a measure for bank profitability). When dividing the sample into preQE and QE phases, ${ }^{6}$ we find that QE announcements had no significant impact on bank equities but the effect on inflation expectations is more positive. QEs continue to lower sovereign yields and narrow spreads, but the marginal effect seems to be diminishing. These results are from a traditional event study framework using announcement dummies for the period January 2007 to June 2016. Using the modified event study approach, we find that the signaling channel of

\footnotetext{
${ }^{5}$ Some others have tried to account for anticipation using news flows in asset price regressions in event studies. For example, see a series of blog posts from the Bank of England's, Bank Underground blog.

${ }^{6}$ We choose the time periods based on the fact that Mario Draghi, president of the ECB, alluded to the possibility of outright $\mathrm{QE}$ in the euro area for the very first time with his speech at the Jackson Hole Economic Symposium on August 22, 2014. In particular, after widespread acknowledgement of deflationary pressures in the euro area, this speech marked a turning point in ECB's policy objectives. From this point on QE announcement refers to programmes announced on January 22, 2015 (QE1) and March 10, 2016 (QE2).
} 
the monetary policy play an important role throughout the entire sample. As expected, the portfolio rebalancing channel becomes more prevalent only during the QE phase especially on exchange rates and inflation expectations. Finally, spillovers to the non-euro area financial markets are largely transmitted through portfolio rebalancing channel, resulting in statistcially significant appreciation of local currencies and lowering of sovereign bond yields.

The rest of the paper is organized as follows. Section 2 introduces and describes the measure of monetary policy surprise. Section 3 discusses the data and the empirical framework adopted. Section 4 discusses our empirical findings, and section 5 offers concluding remarks.

\section{A Measure of Monetary Policy SurPrise}

Traditionally, monetary policy surprises are considered as the difference between expected and realized federal funds target rates at the current FOMC meeting (Kuttner, 2001; Bernanke and Kuttner, 2004; Gürkaynak, 2005). The futures contracts expiring in the months of future FOMC meetings are used to measure market's expectation of fed fund rates from the announcement; the unexpected component of the announcement is obtained as the difference between the yield of the next expiring futures on Federal Funds, taken just before an FOMC announcement, and the target Federal Funds rate announced by the Fed. To capture different dimensions of monetary policy surprises, Gürkaynak, et al. $(2005,2007)$ extract two factors from a set of short-term federal funds futures and eurodollar futures rates by maturity to isolate the surprise on the short-term policy rate ("current federal funds rate target" or timing factor), and the surprise on interest rate path ("future path of policy" or path factor). They find that 75 to 90 percent of the variation in asset prices in response to monetary policy announcements can be explained by the path factor.

Chen et al. (2014) extends Gürkaynak, et al. (2005, 2007)'s work by extracting the factors of monetary surprises from longer term bond yields, that is changes in U.S. bond yields across the yield curve from 1-year to 30-year maturities. Rather than trying to capture the timing factor of Gürkaynak, et al. (2005, 2007), Chen et al. (2014) relates the two factors with (i) the signaling channel of monetary policy (similar to the path factor in Gürkaynak, et al. (2005, 2007)); and (ii) other channels and information that are likely to affect longer-term interest rates and term premia, which are typically associated with portfolio rebalancing channel. Chen et al.'s approach is more relevant in the case of ECB QEs. The announcement of unconventional measures such as asset purchases or forward guidances convey information that influences the long-end of the yield curve, including the supply of bonds avaialabe to private investors, longer-term risks to (or uncertainty about) growth and inflation, and changes to central bank preferences and objectives (Chen, et al., 2014). 
Hence, in a similar vein, we extract two factors from the changes in "euro area bond yields" across the yield curve from 1-year to 30-year maturities, using the standard factor analysis. We construct the "euro area yield curve" by taking an average of the German, French, Italian and Spanish bond yields weighted by their respective total outstanding government debt. The daily bond yield data is taken from Bloomberg and changes in yields are computed as the difference between the close of the announcement day to the close of the day prior to the announcement. For the extraction, we consider all Governing Council meetings of the ECB from its existence and all UMP related announcements based on the list from Falagiarda, et al., (2015), ${ }^{7} 283$ events in total. The two factors extracted account over 98 percent of the variation in euro area bond yields we construct as a weighted average of the four major member states. The factors are then rotated using varimax rotation method that maximizes the sum of the variance of the squared loadings.

Figure 1 shows the loadings plot. The first factor, which we call the market factor, has a very high loading on longer-term bonds from 5 to 30 years. This factor captures the portfolio rebalancing channel of the monetary policy. That is, any additional information on the demand/supply of bonds, longer-term macroeconomic risks, and changes to central bank preferences and objectives. The second factor, the signal factor, has very high loadings on shorter-term bonds from 1 to 3 years, the typical timeframe to which most central banks commit the course of its policy. ${ }^{8}$ The signal factor reflects the signaling channel of the monetary policy (similar to the path factor in Gürkaynak, et al. $(2005,2007)$ ), capturing the future path of the short term interest rates. ${ }^{9}$

\section{Figure 1. Correlation between the Factors and Bonds of Different Maturity}

\footnotetext{
${ }^{7}$ We do not extract surprises for every day. The monetary policy surprises were constructed using days when there was a meeting of ECB's governing council (all meetings from its inception) and all UMP related events identified by Falgiarda et al (2015). The choices of days are in line with the literature on monetary policy surprises and ensures that the surprise factor is only capturing the information primarily regarding the monetary policy announcement. The list of UMP events is constructed by extending the series in Falagiarda, et al., (2015) from January 2015 to June 2016. It includes press conferences, press releases and speeches, and reported in the ECB media website.

${ }^{8}$ The bond yields data used to construct the euro area bond yields at 1 year maturity is missing for France, Italy and Spain for the initial observations and might explain the position of the 1 year bond yields in the loadings plot.

${ }^{9}$ Chen et al. (2014) also shows the interpretation of each factors to be robust by calculating the correlations of the market factor and the signal factor with the term-premium component (associated with the portfolio rebalancing channel of monetary policy) and risk-neutral expectations of future short-term rates (commonly thought to react to the signaling channel of monetary policy) extracted from term structure models respectively. They further argue that the models, the two factors identified in this approach differ in important ways. First, they are orthogonal to one another and comparable in size, a characteristic that facilitates empirical analysis. Second, they are not affected by model specification as different affine term structure model specifications can lead to rather different yield curve decompositions.
} 


\section{(Factor Loadings)}

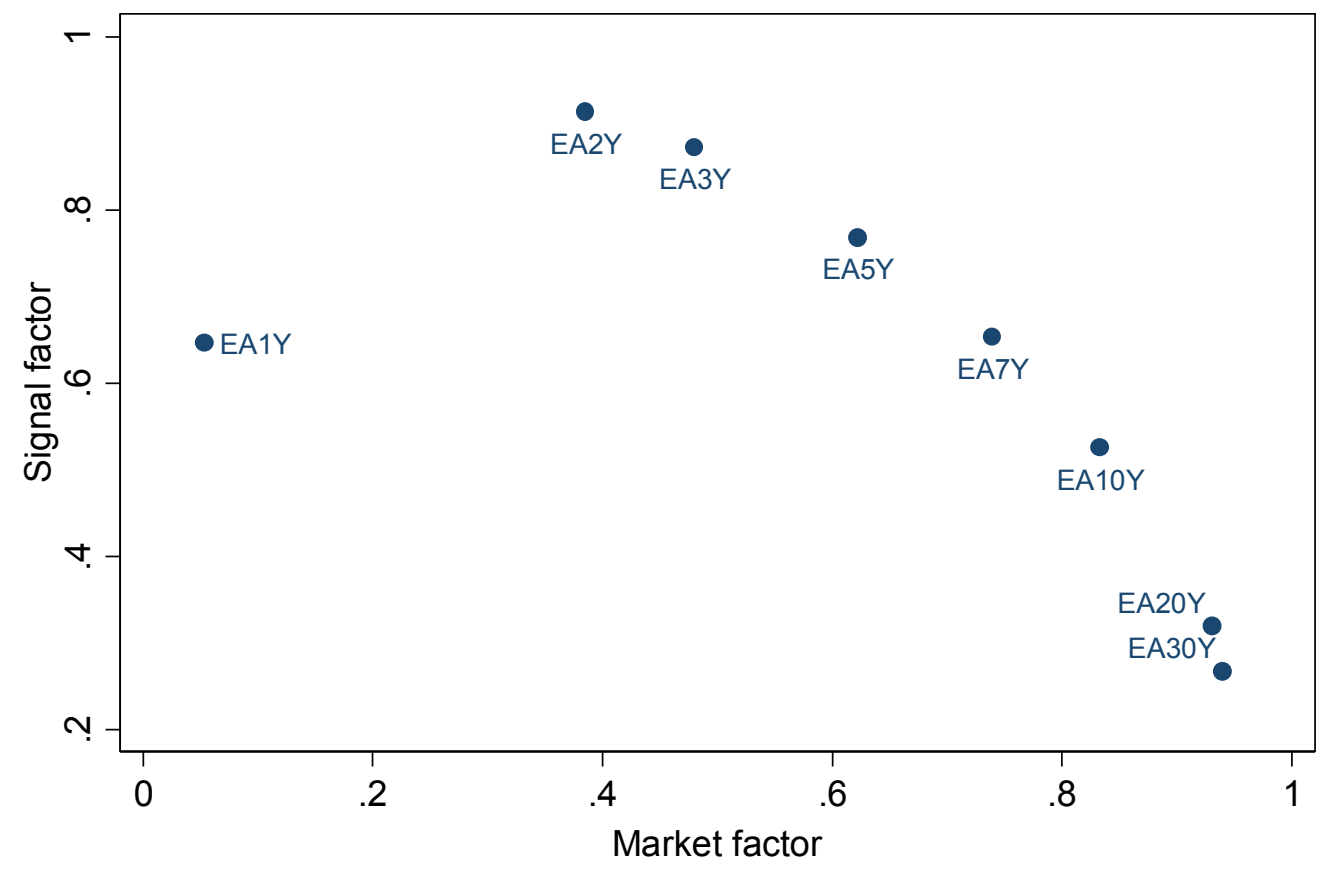

Rotation: orthogonal varimax Method: principal factors

Source: Authors' calculations

\section{Patterns of Monetary Policy Surprises}

In this section, we document the patterns of monetary policy surprises across different phases of ECB's monetary policies: the conventional monetary policy phase (January 1, 1999 to December 31, 2006), the pre-QE phase of ECB's UMPs (January 1, 2007 to July 31, 2014) and the QE phase of UMPs (August 1, 2014 to June 29, 2016).

Figure 2 shows ECB's monetary policy surprises decomposed into the market factor (Panel A) and the signal factor (Panel B) across monetary policy phases. Each green bar in the graphs represents surprises extracted on the days of an ECB governing council meeting or days of any UMP events as identified and extended based on Falagiarda, et al., (2015). Positive values for individual bars indicate that the relevant announcement surprised markets on the hawkish side (tightening surprises). These tightening surprises encompass both less accomodative announcements and more aggressive tightening than market's prior expectations. Similarly, negative bars represent loosening or dovish surprises. It is possible that monetary easing announcements could have a positive (negative) value if more (less) aggressive loosening was expected by the markets. 
Figure 2. Monetary Policy Surprises

\section{Panel A: Market Factor}

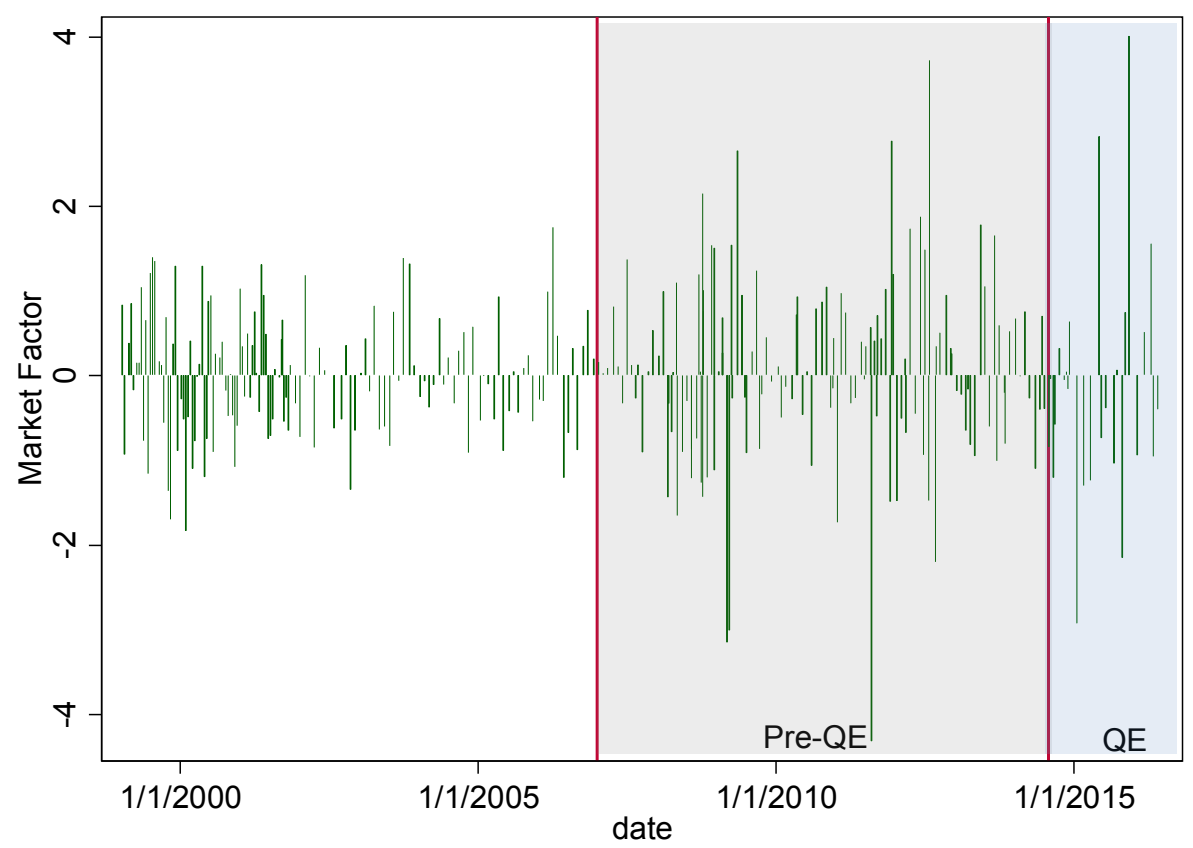

Panel B: Signal Factor

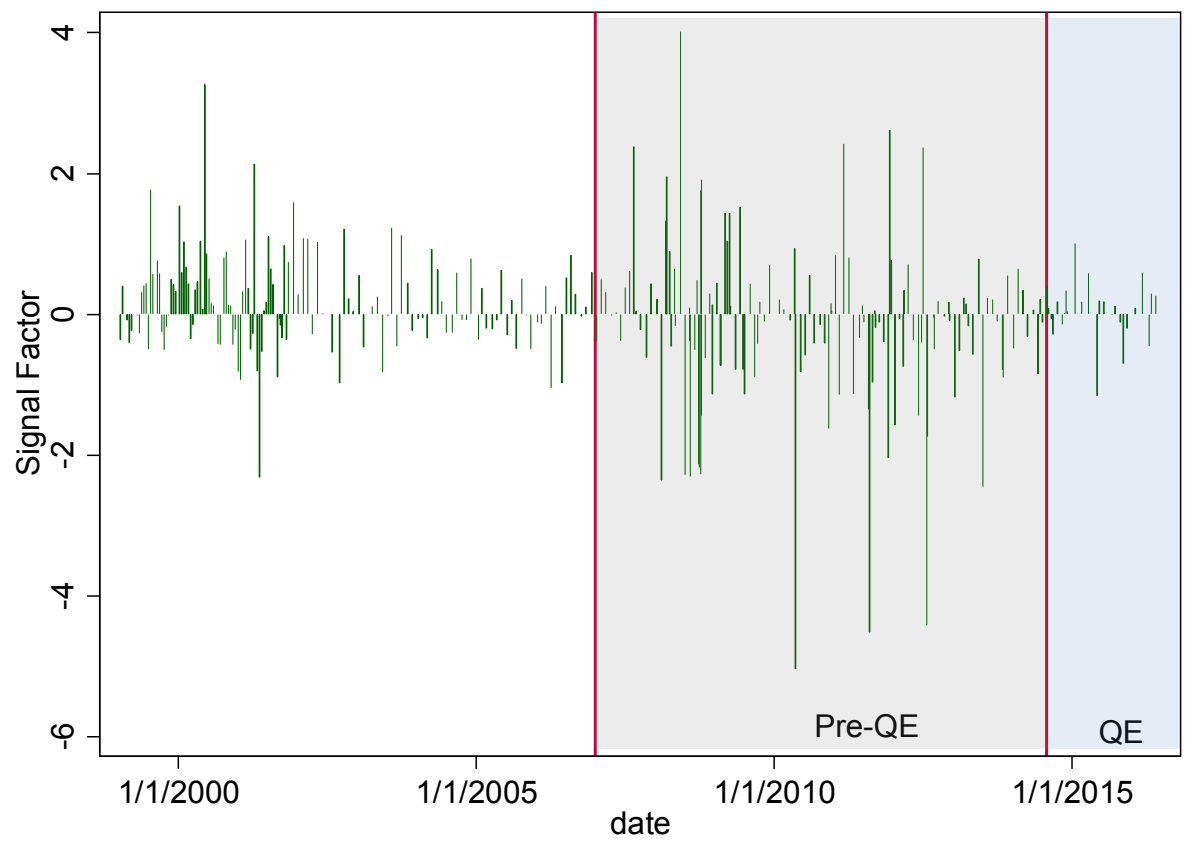

Source: Authors' calculations 
Figure 3. Distribution of Monetary Policy Surprises

Panel A: Market Factor

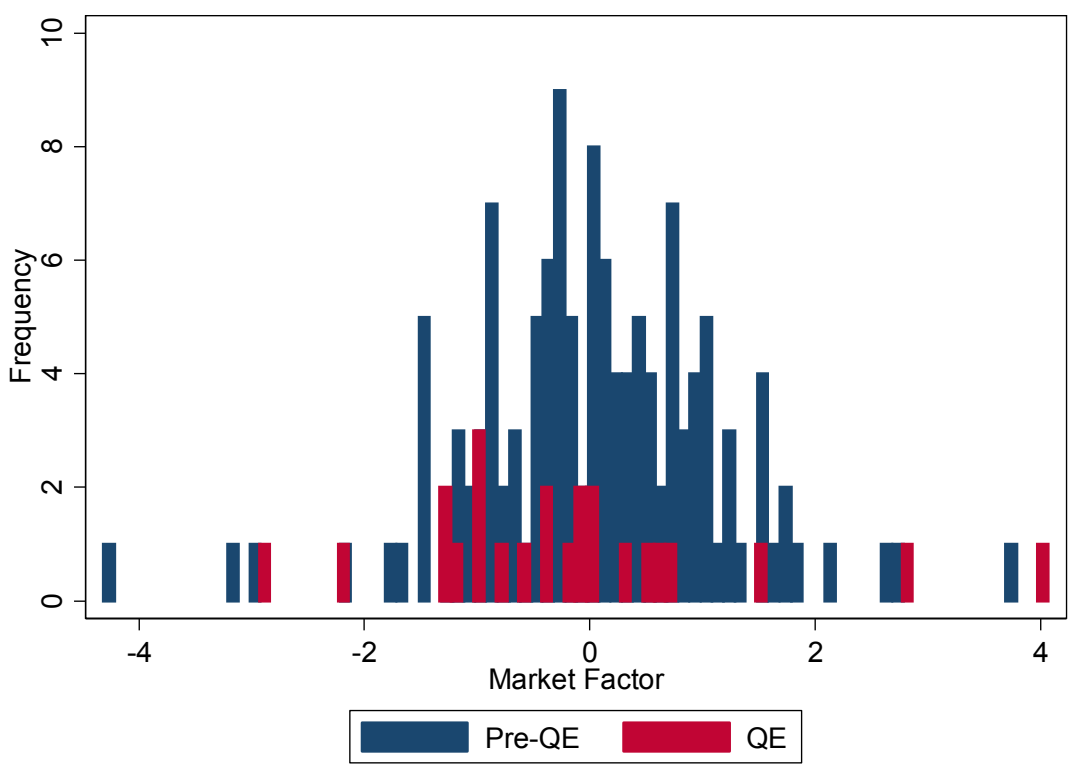

Panel B: Signal Factor

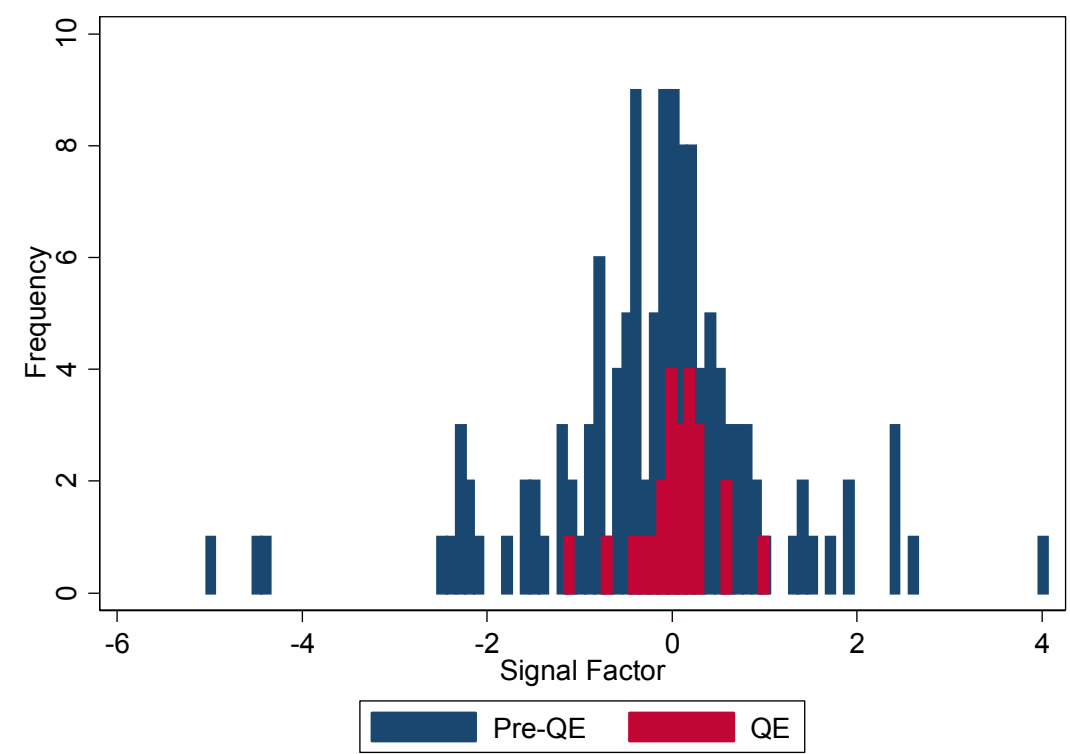

Source: Authors' calculations 
The monetary policy announcements seem to have triggered more surprises to the market since the onset of unconventional monetary policy measures, especially the market factor associated with the term premium. The signal factor, however, declined in magnitude relatively (smaller than the market factor) during the QE period, suggesting falling market surprises on the path of short term interest rates.

The explicit commitment to offset deflationary pressures and unsterilized nature of asset purchases during the new wave of ECB's unconventional monetary policies appear to have increased the credibility of the communication compared with those undertaken in the first phase of unconventional phase. Credible commitment and the use of new instruments by the ECB (i.e. forward guidance and pure quantitative easing as in we understand in the context of the US and the UK) have contributed to the effectiveness of market factor noted above. Forward guidance provides information on the expected future path of the short term interest rates a key component of the long term interest rate. At the effective lower bound, forward guidance is expected to affect the long-end of the yield curve and hence to be captured by the market factor. Similarly with regards to quantitative easing announcements (Jan 2015 and March 2016), unsterilized asset purchases are expected to affect the longer end of the yield curve ( 2 to 30 years), and consequently captured by market factor.

Figure 3 shows the distribution of the surprises. ${ }^{10}$ Both the market factor and signal factor had negative (loosening) biases during the UMP (both Pre and QE phases), which is consistent with a prolonged period of accomodative monetary policies after the crisis. The slightly counterintuitive results are positive market factor surprises on June 3, 2015 (2.8) and December 3,2015 (4.0). This too is not totally surprising. Markets, for example, were anticipating a larger than 10 basis point cut in the deposit facility rate and an a more aggressive expansion of the asset purchase programme on 3 December 2015. Hence, despite an easing announcement, the market surprise is positive, reflecting a tighter than expected monetary stance, confirming the need to control for surprises and anticipation affects to fully understand the effect of UMP announcements.

\section{Table 1. Events under consideration and surprises}

\footnotetext{
${ }^{10}$ A key caveat here is that we only have 24 events during the QE phase as opposed to 129 events during the preQE period.
} 


\begin{tabular}{llccc}
\hline \multicolumn{1}{c}{ Date } & \multicolumn{1}{c}{ Event } & Phase & Market Factor Signal Factor \\
\hline & & & & \\
May 7, 2009 & Covered bond purchase program 1* & Pre-QE & 2.7 & -0.8 \\
May 10, 2010 & Securities market program** & Pre-QE & 0.9 & -5.0 \\
October 6, 2011 & Covered bond purchase program 2* & Pre-QE & 0.4 & -0.1 \\
July 26, 2012 & "...whatever it takes..." speech & Pre-QE & -1.5 & -4.4 \\
August 2, 2012 & Possibility of Outright monetary transactions program & Pre-QE & 3.7 & -1.8 \\
September 6, 2012 & Technical features of outright monetary transactions program & Pre-QE & -2.2 & 0.0 \\
June 5, 2014 & Negative interest rate policy & Pre-QE & -0.4 & -0.8 \\
August 25, 2014 & Jackson Hole speech & QE & -1.2 & -0.1 \\
January 22, 2015 & Public sector purchase program & QE & -2.9 & 1.0 \\
March 10, 2016 & Corporate sector purchase program & QE & 0.5 & 0.6 \\
\hline
\end{tabular}

* Announced with 1-year LTROs

** Announced on May 9, 2010, a Sunday, so that incorporated into market prices on 10 May.

*** Since an afternoon speech on August 22, 2014, a Friday, in the US incorporated into market prices on 25 August.

Source: Authors' calculations

We also summarize the monetary surprises on the key announcement dates in Table 1. A noteworthy observation is that the signal surprises are large and broadly negative for the events in the pre-QE phase whereas the market factor becomes negative and larger than signal factor for the events during the $\mathrm{QE}$ phase; highlighting a more important role of portfolio rebalancing channel in monetary policy transmission during the QE phase. We also clearly see that surprises on the days of more aggressive easing (or less aggressive tightening) are negative, while those on the days of less aggressive easing (or more aggressive tightening) are positive. As expected, “...whatever it takes speech..." had a large negative surprise both on market and signal factors. Similarly, 10 March 2016 is an interesting case in point for a lesser than market expected easing. Although the announcement included new key features to the the asset purchase programme, the suggestion that ECB did not anticipate further interest rate cuts into negative territory potentially explains the slight positive market and signal factors. These examples reinforce the need to control for the unexpected component of the monetary policy announcement and specifically account for market factor in addition to the traditional signal factor when evaluating the market impact and spillovers of the UMPs.

\section{EMPRIICAL FRAMEWORK}

Our empirical framework is commonly utilized in the event study literature. We set up a daily frequency regression framework to assess the market impact of the ECB's monetary policy announcements using the ordinary least squares estimation with robust standard errors. We consider a two-day event window for our analysis over the period 1 Jan 2007 to 29 June 2016. Our empirical framework, however, does not address and capture the persistence of the announcement impacts.

$$
\Delta y_{t}=\beta_{0}+\beta_{1} a_{t}+\beta_{2} \Delta v i x_{t}+\beta_{3} \Delta i_{t}+\beta_{4} \Delta i_{t}^{U S}+\beta_{5}^{\prime} Z_{t}+e_{t}
$$


where the deprendent $\mathbf{y}_{\mathbf{t}}$ is the financial variable of interest, including the return on the main equity index, banking equity index, and NEER, as well as the 10-year government bond yields, 5 -year sovereign credit default swap rates, and 5-year zero coupon inflation swap rates. at is the announcement dummy or the monetary policy surprises extracted from the yield curve. The announcement dummy takes a value of one for ten events listed in Table 1 including key policy announcements and speeches by Mario Draghi. To identify channels of spillovers, we replace announcement dummies with the values of market and signal surprises on the days of the announcements. Controls include vixt, "European VIX", that measures implied volatility of near term options on the EuroStoxx 50 index. $\mathbf{i}_{t}$ is the ECB's main refinancing rate, the key policy rate; and $\mathbf{i}_{\mathbf{t}}{ }^{\text {US }}$ US Shadow Federal Funds Rate (Wu-Xia). $\mathbf{Z}_{\mathbf{t}}$ is a set of control variables containing the surprise component of major macroeconomic data releases. These surprise components are constructed by taking the difference between the actual release value and the value expected by market participants as measured by Bloomberg Survey median. The series are standardised. Table A.1 provides the list of variables included as surprises for various regressions. We repeat these regression separately for pre-QE announcements and $\mathrm{QE}$ announcements to examine the distinguished features on the new wave of UMPs from ECB. Finally, we examine the impact of ECB's policies on financial markets in selected non-EA EU countries (Czech, Poland, Romania, Denmark, Sweden). For spillover regrressions, $\mathbf{Z}_{\mathbf{t}}$ is a set of control variables containing the surprise component of major macroeconomic data releases of the country under consideration. Data are taken from Bloomberg primarily, supplemented by Datastream and Haver Analytics.

\section{Results}

Results are organized in two parts. In the first part, we report the aggregate impact of announcements on domestic and foreign financial variables. In the second part, we test the channels of spillovers using two factors extracted from the monetary surprises.

\section{Aggregate Impact}

As shown in Table 2, the UMP announcements ${ }^{11}$ were associated with lower sovereign bond yields $^{12}$ and sovereign credit default swap rates. It also led to higher equity returns in both

\footnotetext{
${ }^{11}$ In alternative regressions, we also considered a specification of announcements with a larger number of events following Falagiarda, et al., (2015) including all events related to ECB press conferences, press releases and speeches, and reported in the ECB media website. We do not find the impact to be of statistically significant suggesting that only key announcements matter for financial markets.

${ }^{12} \mathrm{We}$ acknowledge that coefficients for bond yields need to be interpreted with some caution as we use monetary policy surprises extracted from a yield curve. However, the event study framework is set up to mitigate this issue to some extent. We extract surprises from a composite Euro Area yield curve constructed out of four major economies (Germany, France, Spain and Italy) for daily changes in yields for maturities ranging from 2- to 30-
}

(continued...) 
corporate and banking sector, and raised inflation expectations as measured by 5-year zero coupon inflation swap rates at the euro area level. However, the impact on nominal effective exchange rate was not of statstical significance.

Table 2: Event-study analysis on ECB's unconventional monetary policy announcements (Two-day window)

\begin{tabular}{cccccc}
\hline & Euro Area & DE & FR & IT & ES \\
\hline \multirow{2}{*}{ NEER } & & & & & \\
& -0.201 & - & - & - & - \\
Equity & 0.474 & & & & \\
& $2.6^{* * *}$ & $1.6^{* * *}$ & $2.4^{* * *}$ & $3.7^{* * *}$ & $3.3^{* * *}$ \\
Bank Equity & $(0.00)$ & $(0.00)$ & $(0.00)$ & $(0.00)$ & $(0.00)$ \\
& $4.9^{* * *}$ & $3.6^{* * *}$ & $4.7^{* * *}$ & $5.7^{* * *}$ & $5.2^{* * *}$ \\
Inflation Swap Rates & $(0.00)$ & $(0.00)$ & $(0.00)$ & $(0.00)$ & $(0.00)$ \\
& $3.0^{* *}$ & 1.0 & $4.4^{* * *}$ & 1.6 & 6.1 \\
Bond Yields & $(0.01)$ & $(0.71)$ & $(0.01)$ & $(0.63)$ & $(0.12)$ \\
& - & 3.0 & -2.5 & $-17.1^{* * *}$ & $-24.9^{* * *}$ \\
Sovereign CDS & - & $(0.39)$ & $(0.39)$ & $(0.01)$ & $(0.0)$ \\
& & $-4.7^{* * *}$ & $-6.5^{* * *}$ & $-30.0^{* * *}$ & $-28.9^{* * *}$ \\
& & $(0.00)$ & $(0.00)$ & $(0.00)$ & $(0.00)$ \\
\hline
\end{tabular}

${ }^{* * *} \mathrm{p}<0.01,{ }^{* *} \mathrm{p}<0.05,{ }^{*} \mathrm{p}<0.1$

Source: Authors' calculations

Through country-specific regressions, on Germany, France, Italy and Spain, we observe that the UMP announcements reduced the sovereign spreads between core and periphery economies and boosted equity returns, both in corporate and banking sector, in countries facing more volatile and tighter financial condition, e.g. Italy and Spain. This is encouraging in light of rising concern of financial fragmentation in the euro area. The results on inflation swap rates are more heterogeneous with larger impact on France and Spain, which can be due to country specific factors. While the signs are expected, they are not always statisitically significant.

\section{Table 3: Event-study analysis on ECB's unconventional monetary policy announcements (Two-day window)}

\section{Panel A: Pre-QE announcements}

years. The impact of sovereign yield is studied for individual country bond yields at 10-year maturity and for a two-day event window.

\footnotetext{
${ }^{13}$ We run separate regressions analyzing the impact of ECB's UMP announcements asset prices in selected non-
} EU euro area countries (Czech Republic, Poland, Romania, Denmark, and Sweden). 


\begin{tabular}{cccccc}
\hline & Euro Area & DE & FR & IT & ES \\
\hline \multirow{2}{*}{ NEER } & & & & & \\
& 0.03 & - & - & - & - \\
Equity & $(0.86)$ & & & & \\
& $2.7^{* * *}$ & $1.5^{* * *}$ & $2.5^{* * *}$ & $4.1^{* * *}$ & $3.6^{* * *}$ \\
& $(0.00)$ & $(0.00)$ & $(0.00)$ & $(0.00)$ & $(0.00)$ \\
Bank Equity & $5.5^{* * *}$ & $3.8^{* *}$ & $5.4^{* * *}$ & $6.3^{* * *}$ & $5.8^{* * *}$ \\
& $(0.00)$ & $(0.01)$ & $(0.00)$ & $(0.00)$ & $(0.00)$ \\
Inflation Swap Rates & 2.0 & -0.9 & $3.5^{*}$ & 0.1 & 6.5 \\
& $(0.12)$ & $(0.79)$ & $(0.10)$ & $(0.99)$ & $(0.23)$ \\
Bond Yields & - & $7.3^{* *}$ & 0.6 & $-18.4^{* *}$ & $-29.1^{* *}$ \\
& & $(0.03)$ & $(0.86)$ & $(0.03)$ & $(0.02)$ \\
Sovereign CDS & - & $-6.3^{* * *}$ & $-8.8^{* * *}$ & $-39.9^{* * *}$ & $-39.5^{* * *}$ \\
& & $(0.00)$ & $(0.00)$ & $(0.00)$ & $(0.00)$ \\
\hline
\end{tabular}

${ }^{* * *} \mathrm{p}<0.01,{ }^{* *} \mathrm{p}<0.05,{ }^{*} \mathrm{p}<0.1$

Panel B: QE announcements

\begin{tabular}{cccccc}
\hline & Euro Area & DE & FR & IT & ES \\
\hline \multirow{2}{*}{ NEER } & & & & & \\
& -0.73 & - & - & - & - \\
& $(0.32)$ & & & & \\
Equity & $2.2^{* * *}$ & $1.8^{* * *}$ & $2.1^{* * *}$ & $2.9^{* * *}$ & $2.4^{* * *}$ \\
& $(0.00)$ & $(0.00)$ & $(0.00)$ & $(0.00)$ & $(0.00)$ \\
Bank Equity & $3.3^{*}$ & $3.0^{* *}$ & $2.9^{* *}$ & $4.2^{*}$ & $3.6^{*}$ \\
\multirow{4}{*}{ Inflation Swap Rates } & $(0.08)$ & $(0.05)$ & $(0.05)$ & $(0.10)$ & $(0.08)$ \\
& $5.1^{* * *}$ & $5.1^{* *}$ & $6.4^{* * *}$ & $4.9^{* *}$ & $4.9^{* *}$ \\
Bond Yields & $(0.01)$ & $(0.01)$ & $(0.00)$ & $(0.01)$ & $(0.04)$ \\
& - & -6.8 & $-9.7^{* * *}$ & $-13.6^{* * *}$ & $-14.8^{* * *}$ \\
Sovereign CDS & - & $(0.15)$ & $(0.00)$ & $(0.00)$ & $(0.00)$ \\
& & $-1.003^{*}$ & $-1.078^{*}$ & $-6.432^{* * *}$ & $-3.727^{* * *}$ \\
& & $(0.06)$ & $(0.06)$ & $(0.00)$ & $(0.01)$ \\
\hline
\end{tabular}

${ }^{* * *} \mathrm{p}<0.01,{ }^{* *} \mathrm{p}<0.05,{ }^{*} \mathrm{p}<0.1$

Source: Authors' calculations 
To understand the evolution of the impacts over time, we divide the sample into pre-and post QE phase (see Table 3). The new wave of UMPs indeed generates different market impact in various aspects. First, $Q E$ announcements had a smaller positive impact on bank equity returns when compared to pre-QE announcements. While UMPs in both phases are expected to improve the financial condition, strengthen banks' balance sheets, and unclog the bank lending channel, the latter phase faces a prolonged period of low and increasingly negative interest rate which narrows interest margin and undermines bank profitability, which could partially offset the positive effect. Second, the impact on inflation expectation is more prominent in the $\mathrm{QE}$ phase which is consistent with broader objective of growth and inflation. Third, the pre-QE announcements contributed to greater reduction in sovereign yields, country risk premiums and the compression in sovereign spreads between core and non-core economies; the marginal effect on sovereign yields seems to be diminishing.

\section{Channels of Transmission}

We then replace the announcement dummy with monetary policy (market and signal) surprises on the UMP announcement dates to compare the results with event studies using dummies and to parse the channels of transmission. Expected signs of the coefficients should be opposite to that of the event study using announcement dummies as negative values for market and signal factors represent loosening (or dovish) surprises.

Consistent with the traditional event study approach above, we find that negative (loosening) surprises are associated with increases in equity and bank equity returns and higher inflation expectations. We also noted that loosening surprises lower government bond yields and sovereign credit default swaps. Moreover, from the differences across the impact of announcements on sovereign bond yields and sovereign CDS across main member states indicate that all announcements taken together played a role in reducing country risk premiums in sovereign bond markets. As in event study using dummy variables, we note that the coefficient for exchange rate is not statistically significant when considering all the announcements. Comparing both the channels of transmission, we find that the financial impact is largely transmitted through the signaling channel. However, portfolio rebalancing channels also plays a role in lowering the long term government bond yields (See Table 4).

The interpretation of coefficients, however, is less straight forward. A direct mathematical interpretation of the regression coefficients would indicate the impact "per unit of surprise". However, such an interpretation, on its own is not intuitive and does not provide any meaningful economic information. To address this, we interpret the coefficients using "whatever it takes" speech as a benchmark event for which market factor and signal factor were -1.5 and -4.4 respectively (a large accommodative surprise with on both portfolio rebalancing channel and signaling channel). For example, any UMP event of the magnitude of "whatever it takes" speech leads to a $17(-1.5 * 11.3)$ basis point decline in Spanish sovereign 
bond yields through portfolio rebalancing channel and a $53(-4.4 * 12)$ basis point decline through signaling channel.

As before, we divide the sample into pre-and post- QE phase and conduct the event study analysis using the monetary policy surprises. The regression results are presented in Table 5. We find that the signaling channel, measured by signal factor, dominate during the pre-QE phase, leading to lower government bond yields and sovereign credit default swap rates, and higher bank and corporate equity returns. There is limited impact on inflation expectation and exchange rates.

However, portfolio rebalancing channel, measured by market factor, becomes more important in the new wave of UMPs. QE announcements mainly affect the exchange rates leading to a depreciation of the euro and higher inflation expectation. A QE event of the magnitude of "whatever it takes" speech leads to a $1.1(-1.5 * 0.74)$ percentage depreciation through portfolio rebalancing channel. The impact on sovereign bond yields are less pronounced than that of the pre-QE announcements. Equity and bank equity coefficients also lose significance with QE announcements. 
Table 4: Effects of Signal and Market Surprises: Event-study analysis on ECB's UMP announcements (Two-day window)

\begin{tabular}{|c|c|c|c|c|c|c|c|c|c|c|c|c|}
\hline & \multirow[t]{2}{*}{ Equity } & \multicolumn{3}{|c|}{ Bank Equity NEER Inflation Swap Rates } & \multicolumn{4}{|c|}{10 Year Governt Bond Yields } & \multicolumn{4}{|c|}{5 Year CDS } \\
\hline & & \multicolumn{3}{|c|}{ Euro Area } & $\mathrm{DE}$ & FR & IT & ES & $\mathrm{DE}$ & FR & IT & ES \\
\hline Market Factor & $\begin{array}{l}-0.36 \\
(0.19)\end{array}$ & $\begin{array}{l}-0.68 \\
(0.14)\end{array}$ & $\begin{array}{c}0.11 \\
(0.53)\end{array}$ & $\begin{array}{c}-0.2 \\
(0.79)\end{array}$ & $\begin{array}{c}2.6^{*} \\
(0.07)\end{array}$ & $\begin{array}{l}3.5^{* * *} \\
(0.01)\end{array}$ & $\begin{array}{l}8.4^{* * *} \\
(0.00)\end{array}$ & $\begin{array}{c}11.3^{* * *} \\
(0.00)\end{array}$ & $\begin{array}{c}-0.1 \\
(0.89)\end{array}$ & $\begin{array}{c}0.5 \\
(0.64)\end{array}$ & $\begin{array}{c}6.0 \\
(0.16)\end{array}$ & $\begin{array}{c}9.1^{*} \\
(0.07)\end{array}$ \\
\hline Signal Factor & $\begin{array}{c}-0.98^{* * *} \\
(0.00)\end{array}$ & $\begin{array}{c}-2.21^{* * *} \\
(0.00)\end{array}$ & $\begin{array}{c}0.01 \\
(0.90)\end{array}$ & $\begin{array}{c}-0.9 * \\
(0.10)\end{array}$ & $\begin{array}{c}-1.9 * \\
(0.07)\end{array}$ & $\begin{array}{c}0.5 \\
(0.21)\end{array}$ & $\begin{array}{l}8.1^{* * *} \\
(0.00)\end{array}$ & $\begin{array}{c}12.0^{* * *} \\
(0.00)\end{array}$ & $\begin{array}{l}1.6^{* * *} \\
(0.00)\end{array}$ & $\begin{array}{c}2.4^{*} \\
(0.07)\end{array}$ & $\begin{array}{c}13.9^{* * *} \\
(0.00)\end{array}$ & $\begin{array}{c}14.5^{* * *} \\
(0.00)\end{array}$ \\
\hline $\mathrm{r} 2$ & 0.29 & 0.24 & 0.03 & 0.08 & 0.09 & 0.05 & 0.05 & 0.06 & 0.07 & 0.08 & 0.11 & 0.09 \\
\hline $\mathrm{N}$ & 2369 & 2369 & 2369 & 2369 & 2369 & 2369 & 2369 & 2369 & 2369 & 2369 & 2369 & 2369 \\
\hline
\end{tabular}

\begin{tabular}{|c|c|c|c|c|c|c|c|c|c|c|c|c|}
\hline & \multicolumn{4}{|c|}{ Equity } & \multicolumn{4}{|c|}{ Bank Equity } & \multicolumn{4}{|c|}{ Inflation Swap Rates } \\
\hline & $\mathrm{DE}$ & FR & IT & ES & DE & FR & IT & ES & $\mathrm{DE}$ & FR & IT & ES \\
\hline \multirow[t]{2}{*}{ Market Factor } & -0.24 & -0.35 & -0.5 & $-0.63^{* *}$ & -0.36 & $-1.004^{* * *}$ & $-0.779 *$ & -0.649 & -1.8 & -0.3 & -0.002 & 2.4 \\
\hline & $(0.37)$ & $(0.20)$ & $(0.17)$ & $(0.05)$ & $(0.63)$ & $(0.00)$ & $(0.10)$ & $(0.28)$ & $(0.14)$ & $(0.77)$ & $(0.83)$ & $(0.22)$ \\
\hline \multirow[t]{2}{*}{ Signal Factor } & $-0.412^{*}$ & $-0.921^{* * *}$ & $-1.394^{* * *}$ & $-1.471^{* * *}$ & $-1.018^{* * *}$ & $-2.443^{* * *}$ & $-2.633^{* * *}$ & $-2.181^{* * *}$ & $-1.4^{* *}$ & -1.7 & $-1.5^{*}$ & $-2.5^{* * *}$ \\
\hline & $(0.08)$ & $(0.00)$ & $(0.00)$ & $(0.00)$ & $(0.01)$ & $(0.00)$ & $(0.00)$ & $(0.00)$ & $(0.02)$ & $(0.12)$ & $(0.10)$ & $(0.00)$ \\
\hline r2 & 0.26 & 0.29 & 0.25 & 0.26 & 0.21 & 0.23 & 0.22 & 0.18 & 0.04 & 0.10 & 0.05 & 0.04 \\
\hline $\mathrm{N}$ & 2369 & 2369 & 2369 & 2369 & 2369 & 2369 & 2369 & 2369 & 2369 & 2369 & 2369 & 2369 \\
\hline
\end{tabular}

*** $\mathrm{p}<0.01,{ }^{* *} \mathrm{p}<0.05,{ }^{*} \mathrm{p}<0.1$

Source: Authors' calculations 
Table 5: Effects of Signal and Market Surprises: Event-study analysis on ECB's unconventional monetary policy announcements (Two-day window)

Panel A: Pre-QE announcements

\begin{tabular}{|c|c|c|c|c|c|c|c|c|c|c|c|c|}
\hline & Equity & Bank Equit & NEER & Inflation Swap Rates & \multicolumn{4}{|c|}{10 Year Governt Bond Yields } & \multicolumn{4}{|c|}{5 Year CDS } \\
\hline & \multicolumn{4}{|c|}{ Euro Area } & $\mathrm{DE}$ & FR & IT & ES & $\mathrm{DE}$ & FR & IT & ES \\
\hline Market Factor & $\begin{array}{l}-0.131 \\
(0.64)\end{array}$ & $\begin{array}{l}-0.79 \\
(0.16)\end{array}$ & $\begin{array}{c}-0.12^{* *} \\
(0.04)\end{array}$ & $\begin{array}{l}1.0^{* *} \\
(0.02)\end{array}$ & $\begin{array}{c}1.7 \\
(0.27)\end{array}$ & $\begin{array}{l}2.7^{* *} \\
(0.04)\end{array}$ & $\begin{array}{c}8.8^{* * *} \\
(0.00)\end{array}$ & $\begin{array}{c}12.1^{* * *} \\
(0.00)\end{array}$ & $\begin{array}{c}-0.3 \\
(0.75)\end{array}$ & $\begin{array}{c}0.4 \\
(0.78)\end{array}$ & $\begin{array}{c}5.9 \\
(0.30)\end{array}$ & $\begin{array}{c}10.4 \\
(0.12)\end{array}$ \\
\hline Signal Factor & $\begin{array}{c}-1.0^{* * *} \\
(0.00)\end{array}$ & $\begin{array}{c}-2.3^{* * *} \\
(0.00)\end{array}$ & $\begin{array}{c}0.02 \\
(0.75)\end{array}$ & $\begin{array}{c}-1.0^{* * *} \\
(0.01)\end{array}$ & $\begin{array}{l}-2.0 * * \\
(0.05)\end{array}$ & $\begin{array}{c}0.6 \\
(0.14)\end{array}$ & $\begin{array}{c}8.0^{* * *} \\
(0.00)\end{array}$ & $\begin{array}{c}12.3^{* * *} \\
(0.00)\end{array}$ & $\begin{array}{l}1.7^{* * *} \\
(0.00)\end{array}$ & $\begin{array}{c}2.4^{*} \\
(0.07)\end{array}$ & $\begin{array}{c}14.3^{* * *} \\
(0.00)\end{array}$ & $\begin{array}{c}14.7^{* * *} \\
(0.00)\end{array}$ \\
\hline r2 & 0.29 & 0.25 & 0.03 & 0.09 & 0.082 & 0.047 & 0.052 & 0.058 & 0.07 & 0.08 & 0.11 & 0.09 \\
\hline $\mathrm{N}$ & 2369 & 2369 & 2369 & 2369 & 2369 & 2369 & 2369 & 2369 & 2369 & 2369 & 2369 & 2369 \\
\hline
\end{tabular}

\begin{tabular}{|c|c|c|c|c|c|c|c|c|c|c|c|c|}
\hline \multicolumn{13}{|c|}{$* * * \mathrm{p}<0.01,{ }^{* *} \mathrm{p}<0.05, * \mathrm{p}<0.1$} \\
\hline & \multicolumn{4}{|c|}{ Equity } & \multicolumn{4}{|c|}{ Bank Equity } & \multicolumn{4}{|c|}{ Inflation Swap Rates } \\
\hline & $\mathrm{DE}$ & FR & IT & ES & $\mathrm{DE}$ & FR & IT & ES & $\mathrm{DE}$ & FR & IT & ES \\
\hline \multirow[t]{2}{*}{ Market Factor } & -0.017 & -0.10 & -0.40 & -0.59 & -0.39 & $-1.1^{* * *}$ & -0.81 & -0.89 & -1.2 & 0.9 & 0.8 & $4.6^{* * *}$ \\
\hline & $(0.95)$ & $(0.70)$ & $(0.37)$ & $(0.14)$ & $(0.69)$ & $(0.01)$ & $(0.28)$ & $(0.12)$ & $(0.39)$ & $(0.24)$ & $(0.35)$ & $(0.00)$ \\
\hline \multirow[t]{2}{*}{ Signal Factor } & -0.43 & $-0.95^{* * *}$ & $-1.5^{* * *}$ & $-1.5^{* * *}$ & $-1.1^{* * *}$ & $-2.5^{* * *}$ & $-2.3^{* * *}$ & $-2.8^{* * *}$ & $-1.5^{* * *}$ & $-1.8^{* *}$ & $-1.7^{* *}$ & $-2.6^{* * *}$ \\
\hline & $(0.11)$ & $(0.00)$ & $(0.00)$ & $(0.00)$ & $(0.00)$ & $(0.00)$ & $(0.00)$ & $(0.00)$ & $(0.01)$ & 0.039 & 0.035 & $(0.00)$ \\
\hline r2 & 0.26 & 0.29 & 0.25 & 0.26 & 0.21 & 0.23 & 0.19 & 0.22 & 0.04 & 0.10 & 0.05 & 0.04 \\
\hline $\mathrm{N}$ & 2369 & 2369 & 2369 & 2369 & 2369 & 2369 & 2369 & 2369 & 2369 & 2369 & 2369 & 2369 \\
\hline
\end{tabular}

$* * * \mathrm{p}<0.01, * * \mathrm{p}<0.05,{ }^{*} \mathrm{p}<0.1$ 


\section{Panel B: QE announcements}

\begin{tabular}{|c|c|c|c|c|c|c|c|c|c|c|c|c|}
\hline & \multirow[t]{2}{*}{ Equity } & \multirow{2}{*}{\multicolumn{3}{|c|}{$\frac{\text { Bank Equity NEER Inflation Swap Rates }}{\text { Euro Area }}$}} & \multicolumn{4}{|c|}{10 Year Governt Bond Yields } & \multicolumn{4}{|c|}{5 Year CDS } \\
\hline & & & & & $\mathrm{DE}$ & FR & IT & ES & $\mathrm{DE}$ & FR & IT & ES \\
\hline Market Factor & $\begin{array}{c}-0.6 \\
(0.48)\end{array}$ & $\begin{array}{c}1.3 \\
(0.47)\end{array}$ & $\begin{array}{l}0.7^{* * *} \\
(0.00)\end{array}$ & $\begin{array}{l}-1.9^{* * *} \\
(0.00)\end{array}$ & $\begin{array}{l}4.4^{* * *} \\
(0.00)\end{array}$ & $\begin{array}{l}3.9^{* * *} \\
(0.00)\end{array}$ & $\begin{array}{c}3.4 \\
(0.37)\end{array}$ & $\begin{array}{c}4.5 \\
(0.34)\end{array}$ & $\begin{array}{c}-0.3 \\
(0.52)\end{array}$ & $\begin{array}{c}0.2 \\
(0.76)\end{array}$ & $\begin{array}{c}1.8 \\
(0.38)\end{array}$ & $\begin{array}{c}1.1 \\
(0.44)\end{array}$ \\
\hline Signal Factor & $\begin{array}{c}0.9 \\
(0.65)\end{array}$ & $\begin{array}{c}4.7 \\
(0.32)\end{array}$ & $\begin{array}{c}-0.1 \\
(0.82)\end{array}$ & $\begin{array}{c}4.0^{*} \\
(0.05)\end{array}$ & $\begin{array}{l}-4.3^{*} \\
(0.06)\end{array}$ & $\begin{array}{l}-6.2^{*} \\
(0.08)\end{array}$ & $\begin{array}{c}-8.4 \\
(0.39)\end{array}$ & $\begin{array}{c}-5.3 \\
(0.66)\end{array}$ & $\begin{array}{c}-1.4 \\
(0.32)\end{array}$ & $\begin{array}{c}-0.2 \\
(0.92)\end{array}$ & $\begin{array}{c}-3.9 \\
(0.50)\end{array}$ & $\begin{array}{c}-2.1 \\
(0.63)\end{array}$ \\
\hline r2 & 0.29 & 0.24 & 0.04 & 0.09 & 0.08 & 0.05 & 0.04 & 0.03 & 0.07 & 0.08 & 0.09 & 0.06 \\
\hline $\mathrm{N}$ & 2369 & 2369 & 2369 & 2369 & 2369 & 2369 & 2369 & 2369 & 2369 & 2369 & 2369 & 2369 \\
\hline
\end{tabular}

\begin{tabular}{|c|c|c|c|c|c|c|c|c|c|c|c|c|}
\hline & \multicolumn{4}{|c|}{ Equity } & \multicolumn{4}{|c|}{ Bank Equity } & \multicolumn{4}{|c|}{ Inflation Swap Rates } \\
\hline & $\mathrm{DE}$ & FR & IT & ES & $\mathrm{DE}$ & FR & IT & ES & $\mathrm{DE}$ & FR & IT & ES \\
\hline Market Factor & $\begin{array}{c}-0.69 \\
(0.24)\end{array}$ & $\begin{array}{c}-0.69 \\
(0.34)\end{array}$ & $\begin{array}{c}0.26 \\
(0.84)\end{array}$ & $\begin{array}{c}0.20 \\
(0.85)\end{array}$ & $\begin{array}{c}0.85 \\
(0.60)\end{array}$ & $\begin{array}{c}0.63 \\
(0.69)\end{array}$ & $\begin{array}{c}2.1 \\
(0.35)\end{array}$ & $\begin{array}{c}1.62 \\
(0.40)\end{array}$ & $\begin{array}{l}-1.9^{* *} \\
(0.03)\end{array}$ & $\begin{array}{c}-1.5 \\
(0.15)\end{array}$ & $\begin{array}{l}-1.6^{*} \\
(0.10)\end{array}$ & $\begin{array}{l}-1.6^{*} \\
(0.10)\end{array}$ \\
\hline Signal Factor & $\begin{array}{l}0.267 \\
(0.86)\end{array}$ & $\begin{array}{l}0.482 \\
(0.80)\end{array}$ & $\begin{array}{l}2.854 \\
(0.37)\end{array}$ & $\begin{array}{l}2.374 \\
(0.38)\end{array}$ & $\begin{array}{c}3.5 \\
(0.41)\end{array}$ & $\begin{array}{c}2.8 \\
(0.50)\end{array}$ & $\begin{array}{c}7.1 \\
(0.22)\end{array}$ & $\begin{array}{c}5.8 \\
(0.24)\end{array}$ & $\begin{array}{c}4.2 \\
(0.11)\end{array}$ & $\begin{array}{l}6.5^{* *} \\
(0.03)\end{array}$ & $\begin{array}{c}4.5 \\
(0.14)\end{array}$ & $\begin{array}{c}5.5^{*} \\
(0.06)\end{array}$ \\
\hline r2 & 0.26 & 0.29 & 0.25 & 0.25 & 0.21 & 0.22 & 0.18 & 0.21 & 0.04 & 0.10 & 0.05 & 0.04 \\
\hline $\mathrm{N}$ & 2369 & 2369 & 2369 & 2369 & 2369 & 2369 & 2369 & 2369 & 2369 & 2369 & 2369 & 2369 \\
\hline
\end{tabular}

\footnotetext{
*** $\mathrm{p}<0.01,{ }^{* *} \mathrm{p}<0.05,{ }^{*} \mathrm{p}<0.1$
}

Source: Authors' calculations 


\section{Spillovers}

Given the close trade and financial linkages between the euro area and many non-euro area countries in the EU, ECB's monetary policies have the significant regional spillover implications. Falagiarda et al (2015) and Mircheva, et al (2016) investigate the financial spillovers from the ECB's UMPs on several selected CEE and Nordics countries; and both the papers find strong impact on sovereign bond yields. According to Mircheva, et al (2016), QE announcements following the Jackson Hole speeches had a more significant impact on these countries' currencies against euro compared to earlier UMP announcements. Falagiarda et al (2015), on the other hand, argues that SMP announcements generate larger spillovers than the OMT and PSPP announcements; and the transmission is through different channels depending on the type of announcements.

We revisit the question of spillovers using the monetary policy surprises. ${ }^{13}$ Consistent with the literature, we find strong spillovers from ECB's UMP announcements to sovereign bond yields and exchange rates ${ }^{14}$ in the selected non-EA EU countries specifically for QE announcements. These results are in line with Falagiarda et al (2015) and Mircheva, et al (2016). Mircheva, et al (2016) also find that recent developments in sovereign bond yields and exchange rates in neighboring countries in the aftermath of the new wave of UMPs are indicative of potential spillovers. We notice that local currencies appreciated against euro and sovereign bond yields lowered across countries under consideration as shown in Table 6 Panels A and B (see QE announcements). The results are statistically significant with market factor, as expected, playing a dominant role suggesting the portfolio rebalancing channel of ECB policies. ${ }^{15}$

Little impact is found on corporate and bank equities. ${ }^{16}$ Sovereign CDS, which are largely driven by domestic sovereign risks, experienced little influence from ECB's UMPs; in fact, in

\footnotetext{
${ }^{13}$ We run separate regressions analyzing the impact of ECB's UMP announcements asset prices in selected nonEU euro area countries (Czech Republic, Poland, Romania, Denmark, and Sweden).

14 The impact on the bilateral Danish krone euro exchange rates as expected is minimal. Given the exchange rate regime, we acknowledge that large capital inflows into Denmark in the aftermath of the Swiss National Bank's decision to remove its currency ceiling and consequent pressure on the Danish peg to the euro is not captured in our empirical analysis. We present the results nonetheless for comparison. However, the issue needs to be further explored using other measures including foreign exchange reserves.

15 This result is also in line with ECB's communications about the impact of policies. "QE has several effects. [...] The portfolio rebalancing effect, namely if you buy euro-denominated assets, people who will get cash, will buy perhaps non-euro-denominated assets, and you have a portfolio rebalancing effect through that channel." (Mario Draghi, 4 December 2014)

${ }^{16}$ This issue could be further explored in depth by regrouping the countries with different characteristics such as exchange rate regimes and other country characteristics: DK and SE vs. CZ, RO and PL.
}

(continued...) 
some cases (Czech Republic and Romania) sovereign CDS increased. ${ }^{17}$ Moreover, we noticed some change on the transmission channels. During the pre-QE UMP phase, the UMP announcements led to currency appreciation (against euro) and yield reduction mainly through the signaling channel. The impact is more significant among the emerging EU countries; the yields in Denmark and Sweden, however, increased instead. The signaling channel typically work through restoring confidence in the market for Central bank's role as a lender of last resort, helping to maintain a loose monetary condition and to provide support for the sovereign debt markets or banks in stress. This can have mixed spillover implications on yields in the neighboring countries. On one hand, yields can be higher due to rising confidence on the growth prospects driven by the monetary stimulus; on the other hand, yields can be lower to reflect lower expectation of future yields. The portfolio rebalancing channel becomes more dominant during the QE phase - looser monetary condition in the euro area triggering investors' portfolio adjustment in search for yield in other EU countries, pushing down their yields and appreciating their currencies. Lower term premia in the euro area can also imply a discouraging growth prospect, which creates a weak external environment for other EU countries that rely on external demand and financing from the euro area.

\section{Table 6: Effects of Signal and Market Surprises: Event-study analysis on the spillovers of ECB's UMP announcements (Two-day window)}

\section{Panel A: Exchange Rates}

Exchange Rates

\begin{tabular}{|c|c|c|c|c|c|c|}
\hline & \multicolumn{2}{|c|}{ All announcements } & \multicolumn{2}{|c|}{ Pre-QE announcements } & \multicolumn{2}{|c|}{ QE announcements } \\
\hline & Market Factor & Signal Factor & Market Factor & Signal Factor & Market Factor & Signal Factor \\
\hline \multirow{2}{*}{$\mathrm{CZ}$} & 0.10 & $0.10^{* * *}$ & 0.03 & $0.11^{* * *}$ & $0.24^{* * *}$ & -0.14 \\
\hline & $(0.25)$ & $(0.00)$ & -0.76 & $(0.00)$ & $(0.00)$ & $(0.41)$ \\
\hline \multirow{2}{*}{ RO } & 0.06 & 0.04 & 0.04 & 0.04 & $0.11^{* * *}$ & 0.08 \\
\hline & $(0.24)$ & $(0.35)$ & $(0.53)$ & $(0.39)$ & $(0.00)$ & $(0.26)$ \\
\hline \multirow{2}{*}{ PL } & 0.18 & $0.29 * * *$ & 0.04 & $0.32^{* * *}$ & $0.13^{* * *}$ & $-1.53^{* * *}$ \\
\hline & 0.366 & $(0.00)$ & 0.823 & $(0.00)$ & $(0.00)$ & $(0.00)$ \\
\hline \multirow{2}{*}{ DK } & -0.01 & 0.00 & 0.00 & 0.00 & $-0.03^{* *}$ & 0.05 \\
\hline & $(0.27)$ & $(0.68)$ & $(0.95)$ & $(0.80)$ & $(0.03)$ & $(0.13)$ \\
\hline \multirow{2}{*}{ SE } & 0.00 & 0.05 & -0.12 & $0.06^{*}$ & $0.22 *$ & -0.40 \\
\hline & $(0.98)$ & $(0.31)$ & $(0.24)$ & $(0.08)$ & $(0.06)$ & $(0.18)$ \\
\hline
\end{tabular}

\section{Panel B: 10 Year Government Bond Yields}

\footnotetext{
${ }^{17}$ A potential explanation for an increase in sovereign CDS related to euro-area developments as opposed to domestic reasons is that investors may not treat non-euro denominated government bonds as perfect substitutes for euro-area bonds. While increasing their exposure to non-euro denominated assets they may purchase insurance through CDS in tandem.
} 
10 Year Government Bond Yields

\begin{tabular}{c|cc|cc|cc}
\hline & \multicolumn{2}{|c|}{ All announcements } & \multicolumn{2}{c|}{ Pre-QE announcements } & \multicolumn{2}{c}{ QE announcements } \\
\cline { 2 - 7 } CZ & Market Factor & Signal Factor & Market Factor & Signal Factor & Market Factor & Signal Factor \\
\hline \multirow{4}{*}{ RO } & 0.00 & $0.8^{*}$ & -1.1 & $0.7^{*}$ & $3.5^{* * *}$ & 2.8 \\
& $(0.98)$ & $(0.06)$ & -0.16 & $(0.09)$ & $(0.00)$ & $(0.37)$ \\
& 1.70 & -0.80 & 0.70 & -0.30 & 1.6 & $-9.2^{*}$ \\
PL & $(0.13)$ & $(0.30)$ & $(0.14)$ & $(0.71)$ & $(0.41)$ & $(0.07)$ \\
& 1.30 & $3.2^{* * *}$ & 0.00 & $3.4^{* * *}$ & $4.0^{* * *}$ & $-6.0^{* * *}$ \\
& $(0.41)$ & $(0.00)$ & $(0.59)$ & $(0.00)$ & $(0.00)$ & $(0.00)$ \\
& $2.9^{* *}$ & $-1.8^{* * *}$ & 1.8 & $-1.8^{* *}$ & $6.4^{* * *}$ & -0.80 \\
& $(0.05)$ & $(0.01)$ & $(0.25)$ & $(0.05)$ & $(0.00)$ & $(0.20)$ \\
& 1.7 & -1.6 & 0.0 & $-1.7^{*}$ & $7.1^{* * *}$ & $5.1^{* * *}$ \\
& $(0.28)$ & $(0.16)$ & $(0.82)$ & $(0.06)$ & $(0.00)$ & $(0.00)$ \\
\hline
\end{tabular}


Panel C: 5 Year Sovereign CDS

5 Year Sovereign CDS

\begin{tabular}{|c|c|c|c|c|c|c|}
\hline & \multicolumn{2}{|c|}{ All announcements } & \multicolumn{2}{|c|}{ Pre-QE announcements } & \multicolumn{2}{|c|}{ QE announcements } \\
\hline & Market Factor & Signal Factor & Market Factor & Signal Factor & Market Factor & Signal Factor \\
\hline \multirow{2}{*}{$\mathrm{CZ}$} & -0.69 & $2.13^{* * *}$ & -0.79 & $2.16^{* * *}$ & $-0.84^{* * *}$ & 0.50 \\
\hline & $(0.23)$ & $(0.00)$ & $(0.31)$ & $(0.00)$ & $(0.00)$ & $(0.36)$ \\
\hline \multirow{2}{*}{ RO } & -0.69 & $5.13^{* * *}$ & -0.80 & $5.33^{* * *}$ & $-3.36^{* * *}$ & $-6.94^{* * *}$ \\
\hline & $(0.80)$ & $(0.00)$ & $(0.83)$ & $(0.00)$ & $(0.00)$ & $(0.01)$ \\
\hline \multirow{2}{*}{ PL } & -1.08 & $4.569 * * *$ & -1.82 & $4.680^{* * *}$ & -0.56 & $-1.655^{*}$ \\
\hline & $(0.42)$ & $(0.00)$ & $(0.27)$ & $(0.00)$ & $(0.13)$ & $(0.09)$ \\
\hline \multirow{2}{*}{ DK } & -0.59 & 1.12 & -0.89 & 1.14 & -0.06 & -0.20 \\
\hline & $(0.51)$ & (0.11) & $(0.44)$ & $(0.13)$ & $(0.84)$ & $(0.80)$ \\
\hline \multirow{2}{*}{ SE } & -0.44 & $0.975^{* * *}$ & -0.64 & $0.987^{* * *}$ & 0.05 & 0.68 \\
\hline & -0.57 & $(0.00)$ & -0.54 & $(0.00)$ & $(0.88)$ & $(0.37)$ \\
\hline
\end{tabular}

Panel D: Equity

Equity

\begin{tabular}{|c|c|c|c|c|c|c|}
\hline & \multicolumn{2}{|c|}{ All announcements } & \multicolumn{2}{|c|}{ Pre-QE announcements } & \multicolumn{2}{|c|}{ QE announcements } \\
\hline & Market Factor & Signal Factor & Market Factor & Signal Factor & Market Factor & Signal Factor \\
\hline \multirow{2}{*}{$\mathrm{CZ}$} & 0.20 & -0.04 & 0.18 & -0.07 & $0.74^{*}$ & $1.94^{*}$ \\
\hline & $(0.35)$ & $(0.80)$ & $(0.52)$ & $(0.65)$ & $(0.07)$ & $(0.06)$ \\
\hline \multirow{2}{*}{ RO } & -0.09 & -0.01 & -0.09 & -0.03 & 0.163 & 1.069 \\
\hline & $(0.36)$ & $(0.93)$ & $(0.45)$ & $(0.82)$ & $(0.65)$ & $(0.26)$ \\
\hline \multirow{2}{*}{ PL } & 0.35 & $-0.22^{* *}$ & 0.44 & $-0.22^{*}$ & 0.02 & $-0.62^{* *}$ \\
\hline & $(0.47)$ & $(0.04)$ & $(0.52)$ & $(0.07)$ & $(0.85)$ & $(0.03)$ \\
\hline \multirow{2}{*}{ DK } & -0.05 & -0.29 & -0.04 & -0.29 & 0.02 & 0.14 \\
\hline & $(0.73)$ & $(0.11)$ & $(0.84)$ & $(0.11)$ & $(0.93)$ & $(0.83)$ \\
\hline \multirow{2}{*}{ SE } & -0.06 & -0.08 & 0.00 & -0.11 & 0.15 & $1.516^{* *}$ \\
\hline & $(0.72)$ & $(0.70)$ & $(1.00)$ & $(0.64)$ & $(0.60)$ & $(0.04)$ \\
\hline
\end{tabular}




\section{Panel F: Bank Equity}

\begin{tabular}{|c|c|c|c|c|c|c|}
\hline \multicolumn{6}{|c|}{ Pre-OE announcements } & \\
\hline & Market Factor & Signal Factor & Market Factor & Signal Factor & Market Factor & Signal Factor \\
\hline \multirow{2}{*}{$\mathrm{CZ}$} & 0.42 & -0.17 & 0.49 & -0.22 & 1.01 & $2.99 *$ \\
\hline & $(0.17)$ & $(0.70)$ & $(0.19)$ & $(0.62)$ & $(0.14)$ & $(0.09)$ \\
\hline \multirow{2}{*}{ RO } & 0.54 & -0.03 & 0.71 & -0.03 & -0.13 & -0.77 \\
\hline & $(0.42)$ & $(0.90)$ & $(0.44)$ & $(0.93)$ & $(0.55)$ & $(0.19)$ \\
\hline \multirow{2}{*}{ PL } & -0.25 & -0.119 & -0.39 & -0.161 & 0.81 & 2.67 \\
\hline & $(0.41)$ & $(0.34)$ & $(0.35)$ & $(0.19)$ & $(0.24)$ & $(0.13)$ \\
\hline \multirow{2}{*}{ DK } & 0.39 & $-0.89 * * *$ & 0.52 & $-0.94^{* * *}$ & 0.76 & $2.08^{*}$ \\
\hline & $(0.41)$ & $(0.00)$ & $(0.42)$ & $(0.00)$ & $(0.11)$ & $(0.09)$ \\
\hline \multirow{2}{*}{ SE } & 0.31 & -0.24 & 0.43 & $-0.33^{*}$ & $1.20^{* *}$ & $4.90^{* * *}$ \\
\hline & $(0.41)$ & $(0.15)$ & $(0.34)$ & $(0.05)$ & $(0.04)$ & $(0.00)$ \\
\hline
\end{tabular}

Source: Authors' calculations

\section{Conclusion}

This paper adds to the recent literature that aims at documenting the domestic and spillover impact of ECB's UMPs and the channels of transmission to the financial market and real economy. We focus on distinguishing features of the new wave of UMPs from the earlier ones and identity transmission channels using a modified event study approach.

One encouraging finding is that more recent QEs show signs of supporting inflation expectations; although the positive impact on bank profitability seen during the pre-QE phase is complicated by the offsetting factor from the low interest margin. Exchange rate depreciation becomes more significant following the new wave of QEs, implying some support to the tradable sector from the improved external competitiveness. However, the marginal effect on the reduction of sovereign yields and spreads between core and non-core EAs seem to be diminishing. On channels, while the traditional signaling channel was dominant during the preQE phase; the portfolio rebalancing channel plays an increasingly important role especially in the new wave of QEs. With regards to the international impacts, we observe strong spillovers to non-EA EU countries, in particular, on bond yields and the exchange rates. Like the domestic channels, the portfolio rebalancing channel plays a key role in cross-border spillovers. Our results are broadly in line with the existing literature. Moreover, our premilary exercise 
suggests that both signaling and portfolio rebalancing are important transmission channels of NIRPs; and the market impact from this "price" unconventional monetary policies seem to be larger than quantitative UMPs.

We see two areas for future research stemming from our work. The first is to delve deeper into the impact of the UMPs including negative interest rates ${ }^{18}$ on bank profitability and bank lending using micro data. Second, quantify the real domestic and international macroeconomic effects of the latest round of UMPs in a counterfactual analysis.

\footnotetext{
${ }^{18} \mathrm{We}$ also consider the impact of negative interest rates policies (NIRPs) on asset prices in Appendix I. Using the same empirical framework; we look specifically at the events with negative interest rate announcements by ECB, and compare the results with quantitative UMPs. Preliminary results suggest that NIRP announcements led to higher (bank/corporate) equity returns (both factors), depreciation of the euro (market factor), higher market based inflation expectations (both factors but market factor dominant), lower sovereign bond yields (both factors) and lower sovereign CDS (signal factor). The impact is not statistically significant when we consider the traditional event study approach. However, more importantly, when we utilize the modified event study approach controlling for monetary policy surprises we find that NIRPs have had statistically significant market impact and spillovers to non-euro area EU countries.
} 


\section{BIBLIOGRAPHY}

Abdi, H., 2003. Factor Rotations in Factor Analyses. In: L. M., A. Bryman \& F. T., eds. Encyclopedia of Social Sciences Research Methods. s.1.:Thousand Oaks (CA): Sage.. Altavilla, C., Carboni, G. \& Motto, R., 2015. Asset purchase programmes and financial markets: lessons from the euro area. Working Paper Series 1864, European Central Bank. Altavilla, C., Giannone, D. \& Lenza, M., 2014. The Financial and Macroeconomic Effects of the OMT Announcements. ECB Working Paper Series.

Bernanke, B. S. \& Kuttner, K. N., 2004. What Explains the Stock Market's Reaction to Federal Reserve Policy?. NBER Working Paper No. 10402.

Chen, J., Griffoli, T. M. \& Sahay, R., 2014. Spillovers from United States Monetary Policy on Emerging Markets: Different This Time?. IMF Working Paper No. 14/240.

Ciarlone , A. \& Colabella, A., 2016. Spillovers of the ECB's non-standard monetary policy into CESEE economies. Bank of Italy (Occasional Papers), Volume September.

Constâncio, V., 2015. Assessing the new phase of unconventional monetary policy at the ECB. Panel remarks at the Annual Congress of the European Economic Association,. ECB, 2016. The euro area bank lending survey: Second quarter of 2016.

Eggertsson, G. \& Woodford, M., 2003. Optimal monetary policy in a liquidity trap. National Bureau of Economic Research, Volume No. w9968. .

Falagiarda, M., McQuade, P. \& Tirpák, M., 2015. Spillovers from the ECB's non-standard monetary policies on non-euro area EU countries: evidence from an event-study analysis. Working Paper Series 1869, European Central Bank.

Fratzscher, M., Lo Duca, M. \& Straub, R., 2016. ECB Unconventional Monetary Policy: Market Impact and International Spillovers. IMF Economic Review, 64 (1), pp. 36-74. Gürkaynak, R. S., 2005. Using federal funds futures contracts for monetary policy analysis. Board of Governors of the Federal Reserve System Washington, DC 20551.

Gürkaynak, R., Sack, B. \& Swanson, E., 2005. Do Actions Speak Louder Than Words? The Response of Asset Prices to Monetary Policy Actions and Statements. International Journal of Central Banking, Issue May.

Gürkaynak, R., Sack, B. \& Swanson, E. P., 2007. Market-Based Measures of Monetary Policy Expectations. Journal of Business and Economic Statistics, 25(April), p. 201-212. Kuttner, K. N., 2001. Monetary Policy Surprises and Interest Rates: Evidence from the Fed Funds Futures Market. Journal of Monetary Economics, 47(3), pp. 523-44.

Mircheva, B., Thegeya, A., Turk, R. \& Zhang, Y. S., 2016. Adapting to Spillovers from Unconventional Monetary Policies. Cross-Country Report on Spillovers .

Pereira, I., 2016. Is the ECB unconventional monetary policy effective?. GEE Papers, Volume September.

Rogers, J. H., Scotti, C. \& Wright, J. H., 2014. Evaluating Asset-Market Effects of Unconventional Monetary Policy: A Cross-Country Comparison. International Finance Discussion Papers 1101, Board of Governors of the Federal Reserve System (U.S.).. Varghese, R., 2016. Central bank announcements and inflation expectations: Empirical evidence from the euro area. The Graduate Institute.

Wieladek , T. \& Pascual, A. G., 2016. The European Central Bank's QE: A New Hope. CEPR Discussion Papers. 


\section{Appendix I: The impact of ECB's NIRP announcements}

Starting with an announcement on 5 June 2014, the ECB has introduced negative interest rates policy by cutting the interest rate on its deposit facility below zero. In this section, we summarize the impact of the NIRP announcements on the financial market variables. For the purpose of extracting the impact of the NIRP announcements alone, we only consider the first three dates in Table A1 for our event study regressions. The announcement on 10 March 2016 was accompanied by further asset purchases that are likely to interfere with the effects of NIRP announcements.

Table A1.1: NIRP announcements and monetary policy surprises

\begin{tabular}{lccc}
\hline \multicolumn{1}{c}{ Date } & Deposit Facility Rate & Market Factor & Signal Factor \\
\hline & & & \\
June 5, 2014 & -0.1 & -0.4 & -0.8 \\
September 4, 2014 & -0.2 & -0.6 & -0.3 \\
December 3, 2014 & -0.3 & 4.0 & -0.2 \\
March 10, 2016* & -0.4 & 0.5 & 0.6 \\
\hline
\end{tabular}

Source: Authors' calculations

* The announcement on 10 March 2016 is not considered for the analysis.

Table 2: Event-study analysis on ECB's NIRP announcements (Two-day window)

\begin{tabular}{cccccc}
\hline & Euro Area & DE & FR & IT & ES \\
\hline \multirow{2}{*}{ NEER } & & & & & \\
& 0.39 & - & - & - & - \\
Equity & $(0.44)$ & & & & \\
& -0.39 & -0.88 & -0.38 & 0.56 & 1.01 \\
Bank Equity & $(0.77)$ & $(0.44)$ & $(0.76)$ & $(0.64)$ & $(0.35)$ \\
& 1.55 & 0.19 & 0.44 & 1.55 & $2.90^{* *}$ \\
Inflation Swap Rates & $(0.28)$ & $(0.91)$ & $(0.73)$ & $(0.33)$ & $(0.04)$ \\
& 0.4 & 1.9 & 1.3 & 2.1 & -0.3 \\
Bond Yields & $(0.85)$ & $(0.59)$ & $(0.70)$ & $(0.48)$ & $(0.93)$ \\
& - & 3.4 & 0.3 & -4.7 & -7.5 \\
Sovereign CDS & & $(0.61)$ & $(0.97)$ & $(0.63)$ & $(0.44)$ \\
& - & $-1.0^{* *}$ & $-2.2^{* *}$ & $-11.8^{* * *}$ & $-8.6^{* *}$ \\
& & $(0.03)$ & $(0.03)$ & $(0.03)$ & $(0.03)$ \\
\hline
\end{tabular}

$* * * \mathrm{p}<0.01,{ }^{* *} \mathrm{p}<0.05,{ }^{*} \mathrm{p}<0.1$

Source: Authors' calculations 
In our event study using announcement dummies, we find that although most variables have the expected sign, we do not observe any statistically significant impact except for Italian bank equity returns and sovereign CDS across countries considered (see Table A1.2). Sovereign CDS declined and risk premiums compressed in response to NIRP announcements.

As shown in Table A1.1, monetary policy surprise indices calculated for NIRP announcements suggest loosening (negative) surprises along signal factor as expected. When we account for the size and sign of the monetary policy surprises in our regressions we find NIRP announcements had a significant impact. NIRP announcements led to higher (bank/NFC) equity returns (both factors), depreciation of the euro (market factor), higher market based inflation expectations (both factors but market factor dominant), lower sovereign bond yields (both factors) and lower sovereign CDS (signal factor). See Table A1.3.

With regards to spillovers, higher (NFC) equity returns (market factor), appreciation of local currency against euro (market factor), and lower sovereign bond yields (both factors). We do not observe a significant impact on CDS and results are mixed for bank equity returns. See Table A1.4. 
Table A1.3: Effects of Signal and Market Surprises: Event-study analysis on ECB's NIRP announcements (Two-day window)

\begin{tabular}{|c|c|c|c|c|c|c|c|c|c|c|c|c|}
\hline & Equity & Bank Equity & NEER & Inflation Swap Rates & \multicolumn{4}{|c|}{10 Year Governt Bond Yields } & \multicolumn{4}{|c|}{5 Year CDS } \\
\hline & \multicolumn{4}{|c|}{ Euro Area } & $\mathrm{DE}$ & FR & IT & ES & $\mathrm{DE}$ & FR & IT & ES \\
\hline Market Factor & $\begin{array}{c}-1.1^{* * *} \\
(0.00)\end{array}$ & $\begin{array}{c}-0.9^{* * *} \\
(0.00)\end{array}$ & $\begin{array}{l}0.5^{* * *} \\
(0.00)\end{array}$ & $\begin{array}{c}-1.5^{* * *} \\
(0.00)\end{array}$ & $\begin{array}{l}5.5^{* * *} \\
(0.00)\end{array}$ & $\begin{array}{l}5.8^{* * *} \\
(0.00)\end{array}$ & $\begin{array}{l}6.7^{* * *} \\
(0.00)\end{array}$ & $\begin{array}{l}6.5^{* * *} \\
(0.00)\end{array}$ & $\begin{array}{c}-0.02 \\
(0.90)\end{array}$ & $\begin{array}{c}-0.14 \\
(0.50)\end{array}$ & $\begin{array}{c}-0.10 \\
(0.90)\end{array}$ & $\begin{array}{c}0.41 \\
(0.46)\end{array}$ \\
\hline Signal Factor & $\begin{array}{c}-1.5^{* * *} \\
(0.00)\end{array}$ & $\begin{array}{c}-4.5^{* * *} \\
(0.00)\end{array}$ & $\begin{array}{c}0.2 \\
(0.22)\end{array}$ & $\begin{array}{c}-2.4 \\
(0.25)\end{array}$ & $\begin{array}{l}8.0^{* * *} \\
(0.00)\end{array}$ & $\begin{array}{c}14.2^{* * *} \\
(0.00)\end{array}$ & $\begin{array}{c}24.7^{* * *} \\
(0.00)\end{array}$ & $\begin{array}{c}28.9^{* * *} \\
(0.00)\end{array}$ & $\begin{array}{c}1.8^{* *} \\
(0.05)\end{array}$ & $\begin{array}{l}4.9^{* * *} \\
(0.00)\end{array}$ & $\begin{array}{c}24.8^{* * *} \\
(0.00)\end{array}$ & $\begin{array}{c}20.0^{* * *} \\
(0.00)\end{array}$ \\
\hline r2 & 0.29 & 0.24 & 0.04 & 0.09 & 0.08 & 0.05 & 0.04 & 0.03 & 0.07 & 0.08 & 0.09 & 0.06 \\
\hline \multirow[t]{3}{*}{$\mathrm{N}$} & 2369 & 2369 & 2369 & 2369 & 2369 & 2369 & 2369 & 2369 & 2369 & 2369 & 2369 & 2369 \\
\hline & \multicolumn{4}{|c|}{ Equity } & \multicolumn{4}{|c|}{ Bank Equity } & \multicolumn{4}{|c|}{ Inflation Swap Rates } \\
\hline & $\mathrm{DE}$ & FR & IT & ES & $\mathrm{DE}$ & FR & IT & ES & $\mathrm{DE}$ & FR & IT & ES \\
\hline Market Factor & $\begin{array}{c}-1.1^{* * *} \\
(0.00)\end{array}$ & $\begin{array}{c}-1.1^{* * *} \\
(0.00)\end{array}$ & $\begin{array}{c}-0.6^{* * *} \\
(0.00)\end{array}$ & $\begin{array}{l}-0.9^{* * *} \\
(0.00)\end{array}$ & $\begin{array}{c}-1.3^{* * *} \\
(0.00)\end{array}$ & $\begin{array}{c}-0.9^{* * *} \\
(0.00)\end{array}$ & $\begin{array}{l}-0.6^{* *} \\
(0.02)\end{array}$ & $\begin{array}{c}-1.0^{* * *} \\
(0.00)\end{array}$ & $\begin{array}{c}-2.2^{* * *} \\
(0.00)\end{array}$ & $\begin{array}{c}-2.3^{* * *} \\
(0.00)\end{array}$ & $\begin{array}{c}-1.8^{* * *} \\
(0.00)\end{array}$ & $\begin{array}{c}-2.2^{* * *} \\
(0.00)\end{array}$ \\
\hline Signal Factor & $\begin{array}{c}-0.3 \\
(0.55)\end{array}$ & $\begin{array}{c}-1.5^{* * *} \\
(0.00)\end{array}$ & $\begin{array}{c}-3.4^{* * *} \\
(0.00)\end{array}$ & $\begin{array}{l}-2.9 * * * \\
(0.00)\end{array}$ & $\begin{array}{c}-2.1 \\
(0.17)\end{array}$ & $\begin{array}{l}-2.4^{* *} \\
(0.03)\end{array}$ & $\begin{array}{c}-6.6^{* * *} \\
(0.00)\end{array}$ & $\begin{array}{c}-4.9^{* * *} \\
(0.00)\end{array}$ & $\begin{array}{l}-8.3^{* *} \\
(0.02)\end{array}$ & $\begin{array}{c}-4.7 \\
(0.16)\end{array}$ & $\begin{array}{c}-8.8^{* * *} \\
(0.00)\end{array}$ & $\begin{array}{c}-0.5 \\
(0.91)\end{array}$ \\
\hline r2 & 0.26 & 0.29 & 0.25 & 0.25 & 0.21 & 0.22 & 0.18 & 0.21 & 0.04 & 0.10 & 0.05 & 0.04 \\
\hline $\mathrm{N}$ & 2369 & 2369 & 2369 & 2369 & 2369 & 2369 & 2369 & 2369 & 2369 & 2369 & 2369 & 2369 \\
\hline
\end{tabular}

Source: Authors' calculations 
Table A1.4: Event-study analysis on the spillovers of ECB's NIRP announcements (Two-day window)

\begin{tabular}{|c|c|c|c|c|c|c|c|c|c|c|}
\hline & \multicolumn{2}{|c|}{ Equity } & \multicolumn{2}{|c|}{ Bank Equity } & \multicolumn{2}{|c|}{ Exchange Rates } & \multicolumn{2}{|c|}{ Sovereign Bond Yields } & \multicolumn{2}{|c|}{ Sovereign CDS } \\
\hline & Market Factor & Signal Factor & Market Factor & Signal Factor & Market Factor & Signal Factor & Market Factor & Signal Factor & Market Factor & Signal Factor \\
\hline \multirow{2}{*}{$\mathrm{CZ}$} & $-0.212^{* * *}$ & 0.46 & $-0.391^{* * *}$ & $3.587^{* * *}$ & 0.03 & 0.29 & $0.019^{* * *}$ & $0.082^{* * *}$ & 0.06 & 0.56 \\
\hline & 0 & 0.107 & 0 & 0 & 0.164 & 0.14 & 0 & 0 & 0.545 & 0.718 \\
\hline \multirow{2}{*}{ RO } & $0.107^{* * *}$ & 0.31 & $0.188^{* * *}$ & -0.31 & $0.106^{* * *}$ & -0.03 & $0.040^{* * *}$ & $0.177^{* * *}$ & $0.773^{* *}$ & $18.364^{* * *}$ \\
\hline & 0 & 0.477 & 0.001 & 0.643 & 0 & 0.83 & 0 & 0 & 0.019 & 0 \\
\hline \multirow{2}{*}{ PL } & $-0.287^{* * *}$ & -0.354 & $0.188^{* * *}$ & $-1.308^{*}$ & $0.280^{* * *}$ & $0.956^{* * *}$ & $0.067^{* * *}$ & $0.161^{* * *}$ & 0.05 & 1.72 \\
\hline & 0 & 0.171 & 0.009 & 0.086 & 0 & 0 & 0 & 0 & 0.726 & 0.399 \\
\hline \multirow{2}{*}{ SE } & $-0.676^{* * *}$ & $2.388^{* * *}$ & $-0.566^{* * *}$ & $2.095^{* * *}$ & $0.063^{* * *}$ & -0.227 & $0.057^{* * *}$ & $0.105^{* * *}$ & 0.003 & 0.074 \\
\hline & 0 & 0 & 0 & 0.001 & 0 & 0.186 & 0 & 0 & 0.916 & 0.873 \\
\hline
\end{tabular}

Source: Authors' calculations 


\section{Appendix II: Tables and Figures}

\section{Table A2.1: Macroeconomic Releases}

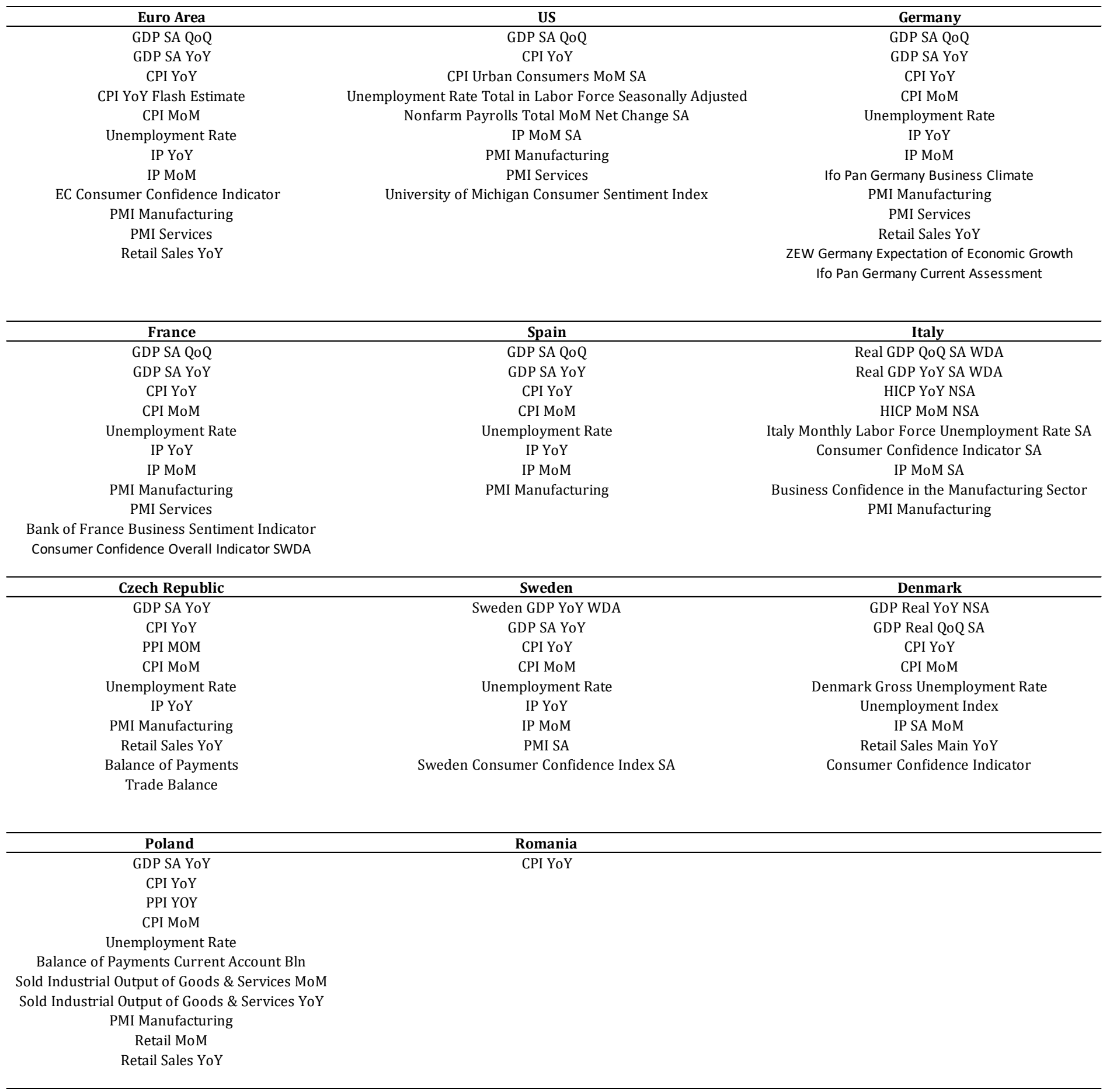

